\title{
Article
}

\section{NGS Techniques Reveal a High Diversity of RNA Viral Pathogens and Papillomaviruses in Fresh Produce and Irrigation Water}

\author{
Marta Itarte 1,2 ${ }^{1}$, Sandra Martínez-Puchol 1,2 $\mathbb{D}$, Eva Forés ${ }^{1,2}$, Ayalkibet Hundesa ${ }^{1,2}$, Natàlia Timoneda $3 \mathbb{D}^{\mathbb{D}}$, \\ Sílvia Bofill-Mas ${ }^{1,2}$, Rosina Girones ${ }^{1,2, *(D)}$ and Marta Rusiñol ${ }^{4}$ (D) \\ 1 Laboratory of Viruses Contaminants of Water and Food, Department of Genetics, Microbiology and Statistics, \\ Faculty of Biology, University of Barcelona, 08028 Barcelona, Spain; mitarte@ub.edu (M.I.); \\ smartinezpuchol@ub.edu (S.M.-P.); efores@ub.edu (E.F.); ahundesa@ub.edu (A.H.); sbofill@ub.edu (S.B.-M.) \\ 2 The Water Research Institute (IdRA), University of Barcelona, 08001 Barcelona, Spain \\ 3 Department of Marine Biology and Oceanography, Institute of Marine Science, Consejo Superior de \\ Investigaciones Científicas (CSIC), 08003 Barcelona, Spain; timoneda@icm.csic.es \\ 4 Institute of Environmental Assessment \& Water Research (IDAEA), Consejo Superior de Investigaciones \\ Científicas (CSIC), 08034 Barcelona, Spain; marta.rosinol@idaea.csic.es \\ * Correspondence: rgirones@ub.edu
}

check for updates

Citation: Itarte, M.; Martínez-Puchol, S.; Forés, E.; Hundesa, A.; Timoneda, N.; Bofill-Mas, S.; Girones, R.; Rusiñol, M. NGS Techniques Reveal a High Diversity of RNA Viral Pathogens and Papillomaviruses in Fresh Produce and Irrigation Water. Foods 2021, 10, 1820. https://doi.org/ $10.3390 /$ foods 10081820

Academic Editor: Dario De Medici

Received: 4 May 2021

Accepted: 31 July 2021

Published: 6 August 2021

Publisher's Note: MDPI stays neutral with regard to jurisdictional claims in published maps and institutional affiliations.

Copyright: (c) 2021 by the authors. Licensee MDPI, Basel, Switzerland. This article is an open access article distributed under the terms and conditions of the Creative Commons Attribution (CC BY) license (https:// creativecommons.org/licenses/by/ $4.0 /)$.

\begin{abstract}
Fresh fruits and vegetables are susceptible to microbial contamination at every stage of the food production chain, and as a potential source of pathogens, irrigation water quality is a critical factor. Next-generation sequencing (NGS) techniques have been flourishing and expanding to a wide variety of fields. However, their application in food safety remains insufficiently explored, and their sensitivity requires improvement. In this study, quantitative polymerase chain reaction (qPCR) assays showed low but frequent contamination of common circulating viral pathogens, which were found in $46.9 \%$ of samples of fresh produce: 6/12 lettuce samples, 4/12 strawberries samples, and 5/8 parsley samples. Furthermore, the application of two different NGS approaches, target enrichment sequencing (TES) for detecting viruses that infect vertebrates and amplicon deep sequencing (ADS), revealed a high diversity of viral pathogens, especially Norovirus (NoV) and Human Papillomavirus (HPV), in fresh produce and irrigation water. All NoV and HPV types found in fresh fruit and vegetable samples were also detected in irrigation water sources, indicating that these viruses are common circulating pathogens in the population and that irrigation water may be the most probable source of viral pathogens in food samples.
\end{abstract}

Keywords: organic food; irrigation water; viral pathogens; food safety; next-generation sequencing; target enrichment sequencing; amplicon deep sequencing; human papillomavirus; norovirus; vertebrate viruses

\section{Introduction}

Consumption and production of fresh fruits and vegetables have increased over the last few years [1] due to population growth, changes in human lifestyles and growing awareness of the benefits of these foods as important sources of nutritional compounds in a healthy and balanced diet [2-4]. This increase in fresh food consumption, often eaten raw or minimally processed, has also been associated with an increase in foodborne infections and disease outbreaks, most of which have been linked to viral origins [2,5,6]. Pathogen contamination can occur at any stage of the food production process, from farm to fork, and irrigation water quality is a critical factor, since it is a potential source of foodborne pathogens [7-10], especially if it comes in direct contact with the edible portion [11]. The microbial quality of irrigation water is affected by a wide range of agricultural, wildlife, and human factors, including: growing season, geographical location, land use, surrounding activities, and environmental conditions [12-14]. Agricultural farms obtain irrigation 
water from sources such as reservoirs, rivers and groundwaters, and in the context of the circular economy, reclaimed water is increasingly becoming an important water source for irrigation.

In 2019, Machado-Moreira et al. collected data from several publications and established that most reported outbreaks related to 'ready-to-eat' food between 1980 and 2016 were due to the consumption of leafy green vegetables, including lettuce and parsley, whereas strawberries ranked first place when considering the number of cases linked to the consumption of a particular foodstuff [15]. This review also reported that leafy green vegetables and soft fruits are, in fact, the main foodstuffs implicated in the transmission of Norovirus (NoV). This virus, excreted in human feces and transmitted by the fecal-oral route, is the leading cause of reported foodborne disease outbreaks and is the main cause of viral gastroenteritis in people of all ages worldwide [5,16-19]. Other enteric viruses, such as Human Adenovirus (HAdV), Rotavirus (RoV), Hepatitis A Virus (HAV), Hepatitis E Virus (HEV), and Astrovirus (Ast), are also important agents in foodborne outbreaks [7,14,20]. Most pathogenic microorganisms of fecal origin that may be present in irrigation water cause gastroenteritis or acute hepatitis, but other pathologies-such as meningitis, myocarditis, and neurological disorders-are also possible [5].

Human papillomavirus (HPV) infects the skin and mucosal epithelia, with effects ranging from benign lesions, such as common warts, to malignant carcinomas, and its occurrence has been described in raw sewage and river waters [21-24], including highand low-risk oncogenic HPV types [21,24]. In fact, HPV excretion in the feces of patients with diarrhea has been described, suggesting transmission through fecal shedding of a virus that was believed to be mainly epitheliotropic and, therefore, pointing to possible transmission through contaminated water [23,25].

In most foodborne viral outbreaks, the link between the contaminated food consumed and the people infected is often not easily established, which makes it difficult to intervene and implement preventive measures [26]. Current guidelines on microbiological irrigation water quality and safety from the European Union rely only on the use of Escherichia coli (EC) as Fecal Indicator Bacteria (FIB) $[27,28]$. However, it is well established that these indicators do not always correlate with important waterborne pathogens that may be present in diverse water sources, such as irrigation water $[5,29,30]$. This is particularly relevant for viral pathogens, which are more resistant to water treatments than bacteria, and thus, FIB might not accurately represent viral inactivation [31-33]. A more suitable indicator for viral fecal contamination is HAdV since it is shed in high concentrations and does not show seasonal variability [34]. HAdV is widely used as a viral fecal indicator; it is highly stable under many environmental conditions and disinfection treatments [29,35-37].

Quantitative polymerase chain reaction (qPCR) is the most commonly used method for the quantification of viruses in food [26], and standardized assays for NoV and HAV (ISO 1526-1:2017, https:/ / www.iso.org/standard/65681.html, accessed on 8 April 2021) have been established [38]. However, the detection of viruses in some food matrices can be difficult due to the presence of inhibitory substances that may impact qPCR detection, leading to false-negative results [39-42]. Next-generation sequencing (NGS) is a promising tool with clear applicability to the detection of viral pathogens in the field of food safety [5,43-45]. The introduction of NGS techniques to this field allows the simultaneous analysis of myriad viral pathogens in a single assay, including pathogens initially not suspected to be present. This is achieved by identifying viral sequences in a sample and comparing them with established sequences in databases [39]. Therefore, NGS has great potential as a viral surveillance tool in the food production chain due to its sensitivity, broad detection range, and detailed information about the detected virus [46,47]. Despite this potential, NGS has still not been widely explored in food safety studies, and technical optimization is needed since there are limitations associated with the presence of inhibitory substances [5]. Several viral metagenomic studies applying NGS techniques in the context of food safety have been published [45,48-53], but to our knowledge, only a few have 
focused on fresh produce: specifically, frozen berries [54], strawberries [39], lettuce [43], parsley [5], and celery [55].

In this study, lettuce, strawberry, and parsley samples grown under organic agricultural practices as well as water irrigation sources were analyzed by qPCR for the presence and concentration of HAdV, which was used as a fecal viral indicator, and other relevant pathogens, such as NoV GI, NoV GII, and HEV. In addition, two different NGS approaches, target enrichment sequencing (TES) for the analysis of viruses that infect vertebrates and amplicon deep sequencing (ADS) for NoV and HPV, were applied to the studied samples to explore the potential application of NGS techniques for viral detection, characterization, and discovery, especially in fresh fruits and vegetables.

\section{Materials and Methods}

\subsection{Organic Food and Water Samples}

Lettuce $(n=12)$, strawberry $(n=12)$ and parsley $(n=8)$ samples were directly purchased from three different organic agriculture producers located in the province of Barcelona (Production Sites 1, 2, and 3 in Table 1), all of which are regulated by Commission Regulation (EC) No. 834/2007, No. 889/2008, and No. 1235/2008 and authorized by Consell Català de la Producció Agrària Ecològica (CCPAE). The irrigation water sources at these production sites were also sampled: $50 \mathrm{~L}$ of groundwater samples $(n=8)$ and $50 \mathrm{~L}$ of river water (flow of $0.48 \mathrm{~m}^{3} / \mathrm{s}$ ) samples $(n=4)$. Fresh produce and irrigation water samples from organic agriculture producers were collected in July 2019.

Table 1. Irrigation water (GW: groundwater; RIV: river), lettuce (LET), strawberry (STR), and parsley (PAR) samples collected from Production Sites 1, 2, and 3 and also alternative irrigation waters, i.e., Llobregat river water (LLRIV) and treated wastewater (SE: secondary effluent; WFPE: subsurface water flow-path effluent), included in this study.

\begin{tabular}{ccccc}
\hline & Irrigation Water & Lettuce & Strawberry & Parsley \\
\hline Production Site 1 & GW1.1 to GW1.4 & LET1.1 to LET1.4 & STR1.1 to STR1.8 & PAR1.1 to PAR1.4 \\
Production Site 2 & GW2.1 to GW2.4 & LET2.1 to LET2.4 & & SAR3.1 to PAR3.4 \\
Production Site 3 & RIV3.1 to RIV3.4 & LET3.1 to LET3.4 & STR3.1 to STR3.4 & PA.1 \\
Llobregat river & LLRIV.1 and LLRIV.2 & & & \\
Treated wastewater & SE and WFPE & & & \\
\hline
\end{tabular}

Barcelona, with nearly 3.5 million inhabitants, has an important agricultural area on the outskirts of the city that uses water from the Llobregat river for irrigation. This river, which flows at $19 \mathrm{~m}^{3} / \mathrm{s}$ over a densely populated area $\left(4948 \mathrm{~km}^{2}\right)$, receives the effluents of more than 50 wastewater facilities and is affected by farming and agriculture activities. Agricultural fields at the Llobregat river delta cover an area of 3489 ha, and organic practices that use animal manure are increasing every year. Llobregat river water samples of $50 \mathrm{~L}$ $(n=2)$ were collected in autumn before the irrigation water intake (Table 1). Two treated wastewater samples $(10 \mathrm{~L})$, collected in winter, were also analyzed in this study, as this type of water is becoming an important source for irrigation, and it is also one of the main inputs of water from small river basins in the studied area (Table 1). The selected wastewater treatment plant (WWTP) is a conventional plant serving 147,000 inhabitants; it applies activated sludge as secondary treatment and a tertiary treatment based on Phragmites australis, a common species of reed that is autochthonous to the region and typically used in constructed wetlands and stream restoration actions [56], enabling the treatment of the secondary effluent in subsurface water flow paths receiving treated wastewater [57]. Secondary effluent $(n=1)$ and subsurface water flow-path effluent $(n=1)$ samples were collected, transported at $4{ }^{\circ} \mathrm{C}$ and processed on the same day of collection.

\subsection{Viral Concentration and Nucleic Acid Extraction}

The leafy sections of lettuce and parsley were cut into pieces with a length of approximately $2 \mathrm{~cm}$ and grouped into $25 \mathrm{~g}$ samples according to ISO 15216-1:2017 [38]. Each sample was washed for $20 \mathrm{~min}$ at $60 \mathrm{rpm}$ in a rocker platform in Whirl-Pak ${ }^{\circledR}$ plastic bags 
(Nasco, Fort Atkinson, WI, USA) containing $40 \mathrm{~mL}$ of Tris-Glycine-Beef Extract Buffer $(\mathrm{pH} 9.5,0.25 \mathrm{~N})$, and 0.25 volumes of $5 \times$ polyethylene glycol/ $\mathrm{NaCl}$ solution was added. After precipitation for $1 \mathrm{~h}$ at $4{ }^{\circ} \mathrm{C}$ and centrifugation $\left(10,000 \times g, 30 \mathrm{~min}, 4^{\circ} \mathrm{C}\right)$, the resulting pellet was resuspended in $500 \mu \mathrm{L}$ of PBS. Viral concentrates were treated with Turbo DNase (Invitrogen, Carlsbad, CA, USA) for $1 \mathrm{~h}$ at $37^{\circ} \mathrm{C}$ to remove free DNA prior to nucleic acid extraction, and $500 \mu \mathrm{L}$ of the DNase-treated viral concentrate was extracted using the NucliSENS ${ }^{\circledR}$ easyMAG system (BioMérieux, Marcy l'Etoile, France). Nucleic acids were eluted in $100 \mu \mathrm{L}$ and stored at $-80{ }^{\circ} \mathrm{C}$ for further analysis in qPCR and NGS assays.

In accordance with ISO 15216-1:2017 [38], $25 \mathrm{~g}$ of strawberries were treated with tris-glycine-beef extract buffer and pectinase at a $\mathrm{pH}$ of 9.5. The solution was centrifuged $\left(8000 \times g, 10 \mathrm{~min}, 4^{\circ} \mathrm{C}\right)$, and the $\mathrm{pH}$ was adjusted to $7.0( \pm 0.2)$ by using $0.1 \mathrm{~N} \mathrm{HCl}$. Then, 0.25 volumes of $5 \times$ polyethylene glycol $/ \mathrm{NaCl}$ solution were added. After precipitation for $1 \mathrm{~h}$ at $4{ }^{\circ} \mathrm{C}$ and centrifugation $\left(10,000 \times g, 30 \mathrm{~min}, 4^{\circ} \mathrm{C}\right)$, the resulting pellet was resuspended in $500 \mu \mathrm{L}$ of PBS and washed with chloroform/butanol. Nucleic acids were extracted from the resulting supernatant using the NucliSENS ${ }^{\circledR}$ easyMAG system (BioMérieux, Marcy $1^{\prime}$ Etoile, France) and stored at $-80^{\circ} \mathrm{C}$ for further analysis in $\mathrm{qPCR}$ and NGS assays.

Viruses were concentrated from irrigation water samples by ultrafiltration using the Long Volume Concentration kit (LVC kit) from InnovaPrep ${ }^{\circledR}$ (InnovaPrep, Drexel, MO, USA) that couples to a Rexeed 25-A polysulfone hollow-fiber ultrafilter. The elution step was performed using wet foam elution cans with Tris-PBS from InnovaPrep ${ }^{\circledR}$ (InnovaPrep, Drexel, MO, USA) and the eluted volume (30-50 mL) was further concentrated using Amicon Ultra-15 devices (50 kDa MWCO) from Millipore (Millipore, Burlington, MA, USA). Viral particles were recovered in a final volume of $200-500 \mu \mathrm{L}$ of eluate and stored at $-80{ }^{\circ} \mathrm{C}$ until further use. Viral concentrates were treated with Turbo DNase (Invitrogen, Carlsbad, CA, USA) for $1 \mathrm{~h}$ at $37^{\circ} \mathrm{C}$ to remove free DNA prior to nucleic acid extraction, and $280 \mu \mathrm{L}$ of the DNase-treated viral concentrate was extracted using the QIAamp ${ }^{\circledR}$ Viral RNA Mini Kit from QIAGEN (QIAGEN, Germantown, MD, USA). Nucleic acids were eluted in $80 \mu \mathrm{L}$ and stored at $-80{ }^{\circ} \mathrm{C}$ for further analysis in qPCR and NGS assays.

\subsection{Viral Quantification}

To evaluate the level of human fecal contamination in fresh food and irrigation water samples, a specific quantitative polymerase chain reaction (qPCR) assay for HAdV was performed using TaqMan ${ }^{\circledR}$ Environmental Master Mix 2.0 (Applied Biosystems, Waltham, MA, USA) with the specific primers and probe previously described [58]. Viral RNA pathogens were also quantified in all samples using the RNA UltraSense ${ }^{\mathrm{TM}}$ One-Step qRTPCR System (Applied Biosystems, Waltham, MA, USA) with specific primers and probes for NoV GI [59-61], NoV GII [62,63], and HEV [64]. All assays were carried out using the Stratagene MX3000P sequence detector system (Agilent Technologies, Santa Clara, CA, USA). The qPCR standards were prepared using synthetic gBlocks ${ }^{\circledR}$ Gene fragments (IDT, Coralville, IA, USA), and serial dilutions were quantified using Qubit 3.0 dsDNA HS Assay Kit (Invitrogen, Carlsbad, CA, USA). All qPCR assays were performed in quadruplicate and included non-template controls.

\section{LOD Determination}

The limit of detection (LoD) of the qPCR was calculated by running six 10-fold dilutions of target DNA/RNA suspensions around the detection end points $(2.5,5,25$, and 50 Genome Copies (GC)/reaction) for each analyzed virus. The concentration that produced at least $95 \%$ positive replicates was assumed to be the LoD of the qPCR assay, which was transformed to the LoD of the entire process using the sample volume or grams tested in each analysis performed. 


\subsection{Target Enrichment Sequencing (TES)}

\subsubsection{Sequence-Independent, Single-Primer Amplification (SISPA)}

A selection of samples that showed the presence of fecal contamination or specific viral pathogens were further analyzed using the TES approach, together with a negative control. Sample preparation prior to library construction consisted of the random tagging of nucleic acids and pre-amplification, allowing the study of both RNA and DNA viruses. This approach was performed following the procedure described previously $[21,65,66]$, with the difference that SuperScript IV enzyme (Invitrogen, Carlsbad, CA, USA) was used in the retrotranscription step. Briefly, retrotranscription was performed using a random nonamer primer and followed by second-strand synthesis using Sequenase 2.0 (Applied Biosystems, Waltham, MA, USA). To obtain enough dsDNA for library construction, nucleic acids were amplified by 25 PCR cycles using AmpliTaqGold (Applied Biosystems, Waltham, MA, USA). The obtained PCR products were cleaned and concentrated with Zymo DNA Clean \& Concentrate kit (Zymo Research, Irvine, CA, USA) and quantified using the Qubit 3.0 dsDNA HS Assay Kit (Invitrogen, Carlsbad, CA, USA).

\subsubsection{Library Construction}

For each sample, libraries were constructed using the KAPA HyperPlus Library Preparation Kit (KAPA Biosystems, Roche, Basel, Switzerland). Briefly, library construction consisted of fragmentation, indexation with KAPA Dual-Indexed Adapters (KAPA Biosystems, Roche, Basel, Switzerland) and amplification of the dsDNA obtained from SISPA. Afterwards, the resulting libraries were quantified using the Qubit 3.0 dsDNA HS Assay Kit (Invitrogen, Carlsbad, CA, USA).

\subsubsection{Capture of Viral Sequences by VirCapSeq-VERT Capture Panel}

Libraries were equimolarly pooled and captured using the VirCapSeqVERT Capture Panel (Roche, Basel, Switzerland). This panel involves the hybridization of probes designed to capture sequences from vertebrate viral pathogens, and it has enabled the detection of viral sequences in complex sample types in previous studies $[21,49,50,67,68]$. After the capture, quality and concentration were checked, and captured libraries were sequenced using an Illumina MiSeq $2 \times 300$ bp platform.

\subsubsection{TES Bioinformatic Processing}

Paired-end FASTAQ files generated from sequencing were analyzed using Genome Detective Virus Tool Version 1.126, a web-based software used to identify, assemble, and classify all known viruses present in NGS data (https://www.genomedetective. com/app/typingtool/virus/, accessed on 4 May 2021) [69]. For more precise and accurate taxonomic classification, human viral contigs obtained with nucleotide identity above $70 \%$ were further processed and queried for sequence similarity using BLASTN against the NCBI GenBank nucleotide collection database [70,71] with Geneious R9.1.8 (https: / / www.geneious.com/, accessed on 4 May 2021) [72].

NCBI Taxonomy standards were followed for the species nomenclature and classification. For specific typing of human caliciviruses, the obtained NoV contigs were further analyzed using the Noronet web-based Typing Tool (version 2.0) developed by RIVM using the updated classification of NoV genogroups and genotypes [73-75].

\subsection{Amplicon Deep Sequencing (ADS)}

\subsubsection{Amplicon Generation}

A selection of samples that showed the presence of fecal contamination or specific viral pathogens were further analyzed using an ADS approach. Sample nucleic acid suspensions were processed by ADS using specific nested PCR for NoV and HPV, previously described as suitable for typing purposes [21,52,76-79], with the incorporation of Illumina adapters in the nested primers. The obtained amplicons were purified from agarose gel using QIAquick 
Gel Extraction (QIAGEN, Germantown, MD, USA) and sequenced with an Illumina MiSeq $2 \times 300$ bp platform.

\subsubsection{ADS Bioinformatic Processing}

Sequences generated from ADS were classified using BLASTN [71] (identity $>90 \%$; coverage $>80 \%$; length alignment: NoV $>200 \mathrm{bp}, \mathrm{HPV}>100 \mathrm{bp}$ ) against a custom database populated with NoV prototype strain sequences from GenBank for the 9 genotypes of genogroup GI and 26 genotypes of genogroup GII determined by VP1, following the NoV classification proposed by Chhabra et al., 2019 [73] (Corrigendum 2020 [74]). The HPV database included sequences obtained from the International HPV Reference Center of Karolinska Institutet (https: / /www.hpvcenter.se/, accessed on 4 May 2021), consisting of all currently described HPV types, from HPV-1 to HPV-227. Other vertebrate papillomavirus genomes obtained from the Papillomavirus Episteme (PaVE) (https:/ / pave.niaid.nih.gov/, accessed on 4 May 2021) were also included in the database.

\section{Results}

\subsection{Virus Quantification in Irrigation Water and Organic Food}

Samples of fresh fruits and vegetables from three organic farmers and irrigation water were tested for the presence of viral contaminants by specific qPCR assays. Low levels of contamination with human pathogenic viruses were detected in $46.9 \%$ of fresh produce samples and $50 \%$ of irrigation water samples (Table S1). The principal agent detected was NoV GII. Llobregat river water and treated wastewater samples showed simultaneous contamination with HAdV, NoV GI, and NoV GII, which were present in higher concentrations than in the rest of the samples.

The presence of HAdV, an indicator of human fecal contamination, was detected in $100 \%$ of the river water samples from the Llobregat river (LLRIV.1 and LLRIV.2) and $100 \%$ of the treated wastewater samples (SE and WFPE). Lower percentages of human fecal contamination were detected in the organic food samples: $37.5 \%$ of parsley samples, $33.3 \%$ of lettuce samples and $16.6 \%$ of strawberry samples analyzed from all production sites. No human fecal contamination was detected in groundwater samples using HAdV quantification. Figure 1 summarizes the mean viral concentrations measured in irrigation waters and harvested food samples from organic production sites by specific qPCR, and Table 2 specifies viral concentrations in alternative irrigation water sources. Further details can be found in Supplementary Materials, Table S1.
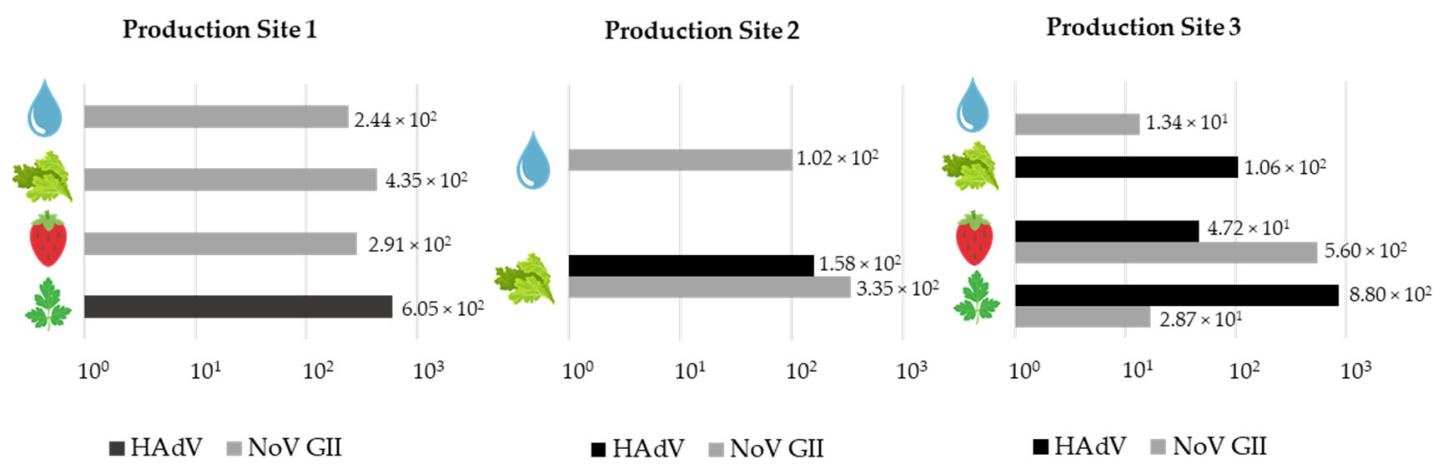

Figure 1. Quantification of viral pathogens in irrigation waters and harvested food samples (lettuce, strawberry, and parsley) from organic Production Sites 1, 2, and 3. Values on the X-axis show the mean concentrations of HAdV and NoV GII detected by qPCR assays, expressed in GC/25 $\mathrm{g}$ for food samples and in GC/L for irrigation water samples. 
Table 2. Viral concentrations obtained from alternative irrigation water sources. Values are expressed in GC/L. ND: not detected. SE: secondary effluent, WFPE: subsurface water flow-path effluent.

\begin{tabular}{cccccc}
\hline & & HAdV & NoV GI & NoV GII & HEV \\
\hline \multirow{2}{*}{ Llobregat river } & LLRIV.1 & $3.47 \times 10^{4}$ & $6.36 \times 10^{3}$ & $1.33 \times 10^{4}$ & ND \\
\cline { 2 - 5 } & LLRIV.2 & $5.99 \times 10^{3}$ & $1.01 \times 10^{4}$ & $4.75 \times 10^{4}$ & ND \\
\hline \multirow{2}{*}{ Treated wastewater } & SE & $8.99 \times 10^{4}$ & $3.77 \times 10^{3}$ & ND & ND \\
\cline { 2 - 5 } & WFPE & $1.88 \times 10^{5}$ & $9.49 \times 10^{3}$ & $6.64 \times 10^{2}$ & ND \\
\hline
\end{tabular}

NoV GI was found in $100 \%$ of Llobregat river water samples and $100 \%$ of treated wastewater samples, but NoV GI contamination was not detected in any of the irrigation water or food samples from the organic production sites. A different distribution was observed for NoV GII, which was widely present in all types of samples. This human viral pathogen was found in all irrigation water sources, including 50\% of groundwater and river water samples, with the highest concentration detected in the Llobregat river sample. NoV GII was also detected in $25 \%$ of the organic food samples, with especially relevant values in all parsley samples collected from Production Site 3. HEV was not detected in any of the samples analyzed in this study.

The detection limits of the assays analyzing food samples were $75 \mathrm{GC} / 25 \mathrm{~g}$ for HAdV, $144 \mathrm{GC} / 25 \mathrm{~g}$ for NoV GI, $1036 \mathrm{GC} / 25 \mathrm{~g}$ for NoV GII, and $1000 \mathrm{GC} / 25 \mathrm{~g}$ for HEV. For the irrigation water samples, the detection limits of the assays analyzing groundwater and river water samples were 2.14 GC/L for HAdV, $4.11 \mathrm{GC} / \mathrm{L}$ for NoV GI, $29.60 \mathrm{GC} / \mathrm{L}$ for NoV GII, and $28.57 \mathrm{GC} / \mathrm{L}$ for HEV. In the analysis of treated wastewater samples, the limits of detection were 10.71 GC/L for HAdV, 20.57 GC/L for NoV GI, 148 GC/L for NoV GII, and $142.86 \mathrm{GC} / \mathrm{L}$ for HEV.

\subsection{Virome of Irrigation Water and Organic Food Using TES}

A selection of samples that showed the presence of fecal contamination or specific viral pathogens were further analyzed using the TES approach. These were: GW1.1, STR1.1, GW2.1, RIV3.1, LET3.4, PAR3.2, LLRIV.1, SE, and WFPE. This approach consisted of capturing sequences from vertebrate viral pathogens during library preparation using the VirCapSeqVERT Capture Panel (Roche, Basel, Switzerland). TES enabled the detection of human and other vertebrate viruses in all irrigation water samples and the identification of a human virus belonging to Caliciviridae in a parsley sample.

All contigs obtained from Genome Detective with nucleotide identity above $70 \%$ were further analyzed, resulting in a total of 77,565 viral reads: 31,634 reads for GW1.1, 44 reads for STR1.1, 977 reads for GW2.1, 1609 reads for RIV3.1, 20 reads for LET3.4, 9 reads for PAR3.2, 7446 reads for LLRIV.1, 16,421 reads for SE and 19,405 reads for WFPE. From the negative control included in the analysis, seven reads were assigned to the bacteriophage family Microviridae, but no other viral assignments were obtained. Further information about the assignment and distribution of all viral reads obtained in different hosts is detailed in Supplementary Materials, Table S2. Most of the reads belonged to bacteriophages $(48.91 \%)$, followed by viruses that infect invertebrates $(33.95 \%)$, plants $(8.28 \%)$, humans $(6.15 \%)$, and other vertebrates $(2.44 \%)$. Using this capture approach, reads assigned to vertebrate viruses were obtained from all irrigation water samples, with the highest diversity found in a Llobregat river water sample (LLRIV.1). The distribution of vertebrate virus reads obtained using TES from different types of irrigation water sources is shown in Figure 2. Of the obtained reads of viruses that infect vertebrates, human viruses were present in greater proportions and accounted for all viruses detected in secondary-treated wastewater. In the Llobregat river, the highest number and diversity of reads were assigned to viruses that infect non-human vertebrates, including feline, canine, porcine, rodent, and cattle viruses belonging to Astroviridae, Caliciviridae, Parvoviridae, and Picornaviridae. Avian, equine and bat viruses belonging to Genomoviridae and Parvoviridae were detected in 
groundwater, whereas river water from Production Site 3 was found to have feline and porcine viral members of Astroviridae and Genomoviridae. Treated wastewater showed a huge proportion of human virus reads, with a low proportion representing canine and cattle parvoviruses in the effluent of subsurface water flow paths.

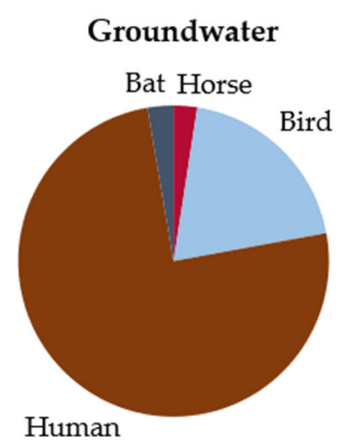

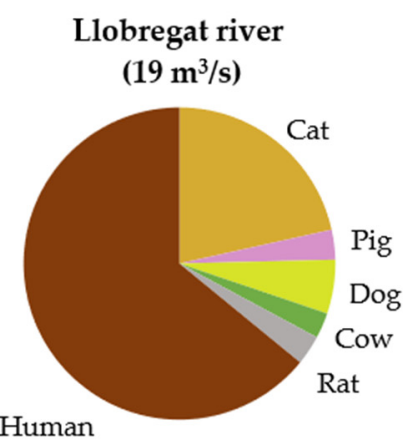

Human

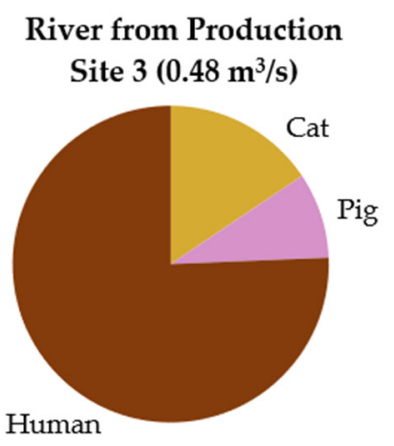

Human
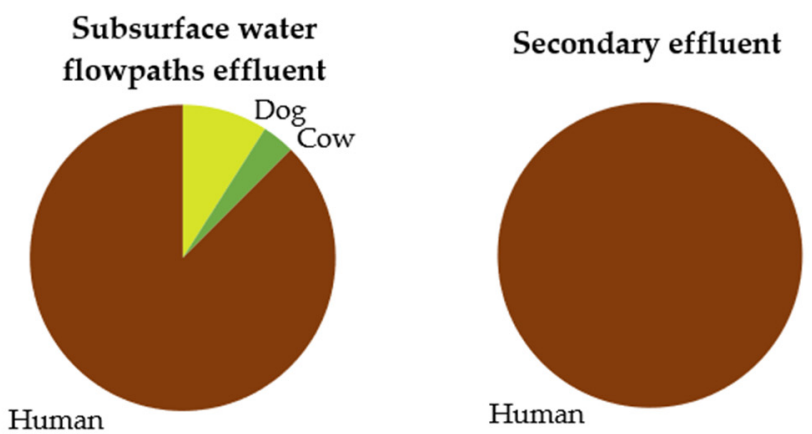

Figure 2. Distribution of vertebrate virus reads among different hosts obtained using target enrichment sequencing from different types of irrigation water sources: groundwater, Llobregat river (flow of $19 \mathrm{~m}^{3} / \mathrm{s}$ ), river water from Production Site 3 (flow of $0.48 \mathrm{~m}^{3} / \mathrm{s}$ ), subsurface water flow-path effluent and secondary effluent. Further details are provided in Supplementary Materials, Table S2.

In food samples, no reads of viruses that infect humans or other vertebrates were obtained from strawberry and lettuce samples, despite the detection of NoV GII and HAdV by GPCR, respectively, and three reads assigned to a human virus belonging to Caliciviridae were obtained from the parsley sample, which showed both HAdV and NoV GII contamination in qPCR assays.

The human pathogenic viruses sequenced using TES are summarized in Table 3. Despite having samples positive for HAdV in the qPCR assay, no assignments belonging to Adenoviridae were obtained. Reads assigned to members of Caliciviridae were obtained from the Llobregat river and the parsley sample, as mentioned previously. Sequences obtained from the Llobregat river were assigned to NoV GI.1, GII.4, and GII.17, the last of which was also the genotype found in parsley. In this study, all sequences assigned to Astroviridae were mainly detected in river water samples. The Llobregat river contained a wide diversity of Human Astroviruses (HAstVs) belonging to different species, including Mamastrovirus 1 (HAstV-1 and HAstV-4), Mamastrovirus 6 (AstV-MLB1 and AstV-MLB2), and Mamastrovirus 8 (HAstV-VA2). HAstV-1 and HAstV-5 were also detected in the river sample from Production Site 3. The presence of HAstV-5 was also detected in subsurface water flow-path effluent. Members of Picornaviridae were detected in river water and treated wastewater. Sequences of Aichivirus A, typed as Aichi virus 1, were sequenced from river water, whereas Salivirus $A$ was found in river water and treated wastewater. Other assignments obtained from irrigation water samples belonged to Circoviridae, with sequences detected in groundwater and secondary effluent, and Parvoviridae, with sequences detected in groundwater, river water, and subsurface water flow-path effluent. 


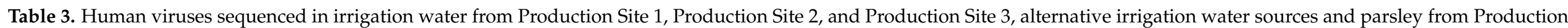
Site 3 analyzed using target enrichment sequencing.

\begin{tabular}{|c|c|c|c|c|c|c|c|c|c|}
\hline \multirow{2}{*}{ Family } & \multirow{2}{*}{ Genus } & \multirow{2}{*}{ Species } & \multirow{2}{*}{$\begin{array}{c}\text { Genogroup/ } \\
\text { Genotype/ } \\
\text { Serotype }\end{array}$} & \multicolumn{6}{|c|}{ Samples } \\
\hline & & & & Contigs & Length (bp) & Nucleotide Identity (\%) & Genome Coverage (\%) & Sample Name & Site \\
\hline \multirow{8}{*}{ Astroviridae } & \multirow{8}{*}{ Mamastrovirus } & \multirow{5}{*}{ Mamastrovirus 1} & \multirow{2}{*}{ HAstV-1 } & 2 & $429-435$ & $98.60-99.07$ & $6.3-6.4$ & RIV3.1 & Production Site 3 \\
\hline & & & & 1 & 551 & 98.19 & 8.1 & LLRIV.1 & Llobregat river \\
\hline & & & HAstV-4 & 2 & $800-3071$ & $92.10-93.62$ & $11.9-45.7$ & LLRIV.1 & Llobregat river \\
\hline & & & \multirow{2}{*}{ HAstV-5 } & 1 & 2869 & 92.36 & 42.2 & RIV3.1 & Production Site 3 \\
\hline & & & & 1 & 808 & 97.65 & 12.1 & WFPE & Treated wastewater \\
\hline & & \multirow{2}{*}{ Mamastrovirus 6} & AstV-MLB1 & 1 & 420 & 95.00 & 6.8 & LLRIV.1 & Llobregat river \\
\hline & & & AstV-MLB2 & 1 & 364 & 98.35 & 5.9 & LLRIV.1 & Llobregat river \\
\hline & & Mamastrovirus 8 & HAstV-VA2 & 1 & 585 & 99.49 & 9.0 & LLRIV.1 & Llobregat river \\
\hline \multirow{4}{*}{ Caliciviridae } & \multirow{4}{*}{ Norovirus } & \multirow{4}{*}{ Norwalk virus } & NoV GI.1 & 1 & 524 & 90.15 & 6.8 & LLRIV.1 & Llobregat river \\
\hline & & & NoV GII.4 & 2 & 689-845 & $92.79-97.98$ & $9.1-11.2$ & LLRIV.1 & Llobregat river \\
\hline & & & \multirow{2}{*}{ NoV GII.17 } & 1 & 282 & 97.28 & 3.8 & PAR3.2 & Production Site 3 \\
\hline & & & & 2 & $632-717$ & $95.66-98.58$ & $8.4-9.5$ & LLRIV.1 & Llobregat river \\
\hline \multirow{2}{*}{ Circoviridae } & \multirow{2}{*}{ Cyclovirus } & \multirow{2}{*}{$\begin{array}{l}\text { Human associated } \\
\text { cyclovirus } 6\end{array}$} & \multirow{2}{*}{ NG12 } & 1 & 1541 & 81.00 & 85.9 & GW1.1 & Production Site 1 \\
\hline & & & & 1 & 433 & 88.29 & 24.10 & SE & Treated wastewater \\
\hline \multirow{5}{*}{ Parvoviridae } & \multirow{4}{*}{ Dependoparvovirus } & \multirow{4}{*}{$\begin{array}{c}\text { Adeno-associated } \\
\text { dependoparvovirus A }\end{array}$} & \multirow{3}{*}{ AAV2 } & 1 & 3040 & 97.27 & 64.9 & RIV3.1 & Production Site 3 \\
\hline & & & & 3 & $932-1216$ & $96.46-98.39$ & $19.9-26.0$ & LLRIV.1 & Llobregat river \\
\hline & & & & 1 & 1438 & 96.45 & 30.7 & WFPE & Treated wastewater \\
\hline & & & AAV6 & 1 & 682 & 79.71 & 14.6 & LLRIV.1 & Llobregat river \\
\hline & Bocaparvovirus & Human bocavirus 3 & Undetermined & 3 & $342-566$ & $95.61-98.25$ & $6.6-10.8$ & LLRIV.1 & Llobregat river \\
\hline \multirow{6}{*}{ Picornaviridae } & \multirow{2}{*}{ Kobuvirus } & \multirow{2}{*}{ Aichivirus A } & \multirow{2}{*}{ Aichi virus 1} & 4 & $348-724$ & $94.31-99.42$ & $4.2-8.8$ & RIV3.1 & Production Site 3 \\
\hline & & & & 5 & 404-952 & $95.79-97.56$ & $4.9-11.5$ & LLRIV.1 & Llobregat river \\
\hline & \multirow{4}{*}{ Salivirus } & \multirow{4}{*}{ Salivirus A } & \multirow{4}{*}{ Undetermined } & 3 & $683-1197$ & $97.21-98.41$ & $8.7-15.3$ & RIV3.1 & Production Site 3 \\
\hline & & & & 2 & $459-552$ & $97.67-98.04$ & $5.9-7.0$ & LLRIV.1 & Llobregat river \\
\hline & & & & 2 & $395-907$ & $96.73-97.97$ & $5-11.6$ & SE & Treated wastewater \\
\hline & & & & 3 & $516-623$ & $97.16-97.87$ & $6.6-7.9$ & WFPE & Treated wastewater \\
\hline
\end{tabular}




\subsection{Diversity of NoV and HPV Sequencing in Irrigation Water and Organic Food Using ADS}

NoV sequences obtained using ADS and classified by VP1 analysis are shown in Table 4. Treated wastewater samples (SE and WFPE) presented the highest diversity of NoV GI, whereas the highest diversity of NoV GII was detected in Llobregat river water (LLRIV.1). NoV GI.4 was the most abundant genotype, and it also accounted for the highest number of NoV reads in Llobregat river water. Among NoV GII sequences, NoV GII.4 and GII.13 were the genotypes that appeared in a greater number of samples, and a high number of reads were obtained mainly from Llobregat river water. Other NoV GII genotypes sequenced from the Llobregat river were GII.2, GII.17, and GII.3.

Table 4. Number of reads of each NoV genotype obtained from a strawberry sample from Production Site 1, irrigation water and parsley samples from Production Site 3 and alternative irrigation water sources using amplicon deep sequencing.

\begin{tabular}{|c|c|c|c|c|c|c|c|c|c|}
\hline & & \multirow{2}{*}{$\begin{array}{c}\text { Production } \\
\text { Site } 1\end{array}$} & \multicolumn{3}{|c|}{ Production Site 3} & \multicolumn{2}{|c|}{ Llobregat River } & \multicolumn{2}{|c|}{ Treated Wastewater } \\
\hline & & & RIV3.1 & PAR3.1 & PAR3.2 & LLRIV.1 & LLRIV.2 & SE & WFPE \\
\hline \multirow{5}{*}{ NoV GI } & GI.4 & 17 & 1 & & 10 & 98,699 & 3 & 15 & 59 \\
\hline & GI.1 & 4 & 2 & & & 15 & & 23,411 & 35,901 \\
\hline & GI.2 & & & & & 8 & 28 & 2 & 2 \\
\hline & GI.3 & & & & & 4 & & 9 & 9500 \\
\hline & GI.5 & & 2 & & & & & 12,021 & 475 \\
\hline \multirow{6}{*}{ NoV GII } & GII.4 & & 1 & & 3 & 9331 & & 3 & 6 \\
\hline & GII.13 & & 2 & 3 & 11 & 49,651 & & & 16 \\
\hline & GII.2 & & & 2 & & 16,933 & & & 4 \\
\hline & GII.17 & & & & & 52 & 1203 & & \\
\hline & GII.3 & & & & & 68 & & & \\
\hline & & $1-10$ & $10-100$ & $100-1000$ & $1000-10,000$ & $10,000-100,000$ & 100,000 & & \\
\hline
\end{tabular}

All food samples presented a lower diversity of NoV, but it is remarkable that all NoV genotypes identified were also found in some of the irrigation water sources. NoV GI members found in food samples, GI.4 and GI.1 in strawberry (STR1.1), and GI.4 in parsley (PAR3.2), were also found in river water and treated wastewater. NoV GII genotypes found in parsley samples, GII.13 and GII.2 in PAR3.1 and GII.4 and GII.13 in PAR3.2, were also found in different irrigation water sources.

HPV and other PV sequences obtained using ADS and classified by L1 analysis are shown in Table 5. The sequences obtained were classified into 16 different HPV types, most of which were members of the genus Betapapillomavirus. Llobregat river water and treated wastewater showed the highest diversity of HPV. HPV-92, HPV-105, and HPV-122, belonging to the species Betapapillomavirus 4, 1, and 2, respectively, were sequenced from all samples. Few Alphapapillomavirus were identified (HPV-177 and HPV-57), and only one Gammapapillomavirus (HPV-4) was found in river and lettuce samples from Production Site 3 , in the Llobregat river and in treated wastewater samples (SE and WFPE). Other PVs not classified as HPV were sequenced: Bos taurus Papillomavirus 7 (BPV-7) from treated wastewater samples and Rattus norvegicus Papillomavirus 2 (RnPV-2) from a Llobregat river sample (LLRIV.2). 
Table 5. Number of reads of each type of human and other Papillomavirus obtained from irrigation water, lettuce, and parsley samples from Production Site 3 and alternative irrigation water sources using amplicon deep sequencing.

\begin{tabular}{|c|c|c|c|c|c|c|c|c|c|}
\hline & & \multicolumn{4}{|c|}{ Production Site 3} & \multicolumn{2}{|c|}{ Llobregat River } & \multicolumn{2}{|c|}{ Treated Wastewater } \\
\hline & & RIV3.1 & LET3.4 & PAR3.1 & PAR3.2 & LLRIV.1 & LLRIV.2 & SE & WFPE \\
\hline \multirow{16}{*}{$\mathrm{HPV}$} & HPV-92 & 1 & 2 & 14 & 6 & 39,158 & 15 & 3 & 16 \\
\hline & HPV-105 & 3 & 45 & 381,617 & 16 & 108 & 197 & 13 & 337,323 \\
\hline & HPV-122 & 2 & 19 & 90 & 50 & 271,741 & 38 & 11 & 114 \\
\hline & HPV-38 & & 152,893 & 14 & 19 & 23 & 1161 & 8 & 7 \\
\hline & HPV-145 & & 102,028 & 17 & 8 & 8 & 150 & 5 & 6 \\
\hline & HPV-177 & 16 & 10 & 3 & & 10 & 20 & 8 & 28 \\
\hline & HPV-182 & 1 & 9 & 580 & & 1 & 1 & 3 & 2 \\
\hline & HPV-37 & & 101 & & 45 & 8 & 9 & 90 & 19 \\
\hline & HPV-76 & & 84 & 6 & & 8 & 87,512 & 4 & 10 \\
\hline & HPV-96 & & 2 & & & 1 & 145 & 4 & 1171 \\
\hline & HPV-4 & 7 & 1 & & & & 2 & 169,019 & 3 \\
\hline & HPV-57 & 6 & 56 & & & & & 76,118 & 1 \\
\hline & HPV-12 & & 20 & 16 & & 79 & 152,261 & 17 & 35 \\
\hline & HPV-8 & & & & & & & 321 & 1 \\
\hline & HPV-17 & & & & & & 2 & & 3 \\
\hline & HPV-196 & & & & & & 49 & 1 & \\
\hline \multirow{3}{*}{ Other PV } & BPV-7 & & & & & & & 1 & 1 \\
\hline & RnPV-2 & & & & & & 17 & & \\
\hline & & $1-10$ & $10-100$ & 100-1000 & $1000-10,000$ & $10,000-100,000$ & $>100,000$ & & \\
\hline
\end{tabular}

As was the case with NoV, all HPV types detected in food samples were also identified in some of the irrigation waters.

\section{Discussion}

At present, quantitative PCR is the most common method applied to the identification of viral contamination in foods. ISO methods focused on qPCR detection and quantification of $\mathrm{NoV}$ and $\mathrm{HAV}$ in different food matrices are available and can be applied even when viral food quality is not included in any regulations. Additionally, HAdV has been suggested and proven to be useful as a viral fecal indicator in water matrices, as this human pathogen is widely detected when water is affected by sewage [80-83] and has been previously detected in conventional and reclaimed irrigation water [29]. In this study, qPCR detected the presence of $\mathrm{HAdV}$ in river water and treated wastewater, indicating that irrigation water is a potential source of human fecal contamination and can potentially become a vehicle for viruses that are transmitted via the fecal-oral route through fresh fruits and vegetables. Using the HAdV indicator, fecal contamination was also detected in the parsley, lettuce, and strawberry samples tested in this study. In 2017, Fernández-Cassi et al. also described the presence of this indicator in water samples from the Besòs river and parsley samples irrigated with this river water source [5]. Other studies have reported HAdV in lettuce and irrigation water [84] and in strawberries collected from European food production chains [85].

In addition to HAdV, other pathogenic viruses were detected by qPCR in this study. NoV GI was found in river water and treated wastewater, but it was not detected in food or irrigation water samples from the organic production sites, despite the fact that some were positive for HAdV. Other studies reported NoV GI contamination in strawberries and suspected irrigation water to be the potential source of contamination [86]. On the contrary, NoV GII was widely present in all types of samples. All irrigation water sources and $25 \%$ 
of food samples showed NoV GII contamination in concentrations consistent with those reported in other studies in which polluted water was suspected to be the contamination source of NoV in fresh fruits and vegetables $[84,85,87]$. Secondary effluent and the effluent of subsurface water flow paths showed similar levels of contamination, indicating that these flow paths were not efficient in eliminating viral contaminants.

HEV was not detected in any of the samples analyzed in this study. Other studies have found HEV to be present in fresh produce: in a pack of frozen raspberries taken from a cold room at point-of-sale [85], in an irrigated, field-grown strawberry sample suspected to be contaminated by irrigation water [86] and in lettuce heads from primary production sites and at point-of-sale [84]. This last study also reported the presence of HEV in irrigation groundwater, which was also described by Rusiñol et al. in an area with intensive pig farming activities [22]. HEV is a zoonotic pathogen that can cause selflimiting or fulminant hepatitis in humans, and it is important to check for its presence since an increasing number of foodborne HEV cases are being reported in Europe, frequently associated with the consumption of pork products [27].

Ultimately, qPCR assays revealed low but frequent contamination associated with human pathogenic viruses in fresh produce and irrigation water, with NoV GII being the principal agent detected. Regarding the NGS data obtained in this study, a targeted assay (TES) was applied by using the VirCapSeqVERT Capture Panel (Roche, Basel, Switzerland) on a selection of samples showing fecal contamination or the presence of specific viral pathogens. This panel employs approximately 2 million biotinylated oligonucleotide probes designed to bind coding sequences of all viral taxa known to infect vertebrates. The TES approach is known to facilitate the detection of vertebrate viruses [68], although some sequences from other viral hosts can be identified [21]. In fact, with the real picture of the virome in mind, vertebrate viruses are commonly found in low proportions with respect to other viruses such as bacteriophages and plant viruses, which have been described as the most abundant in sewage samples $[65,88]$. TES has been successfully employed in previous studies $[21,49,50,67,68]$ to improve the detection of vertebrate viruses of interest that would otherwise be difficult due to their low concentrations in environmental samples. Recently, the VirCapSeqVERT Capture Panel was applied in a metagenomic study to evaluate NoV genomic diversity in oysters [50], but to date, no studies have applied this capture approach to fresh fruits and vegetables. In this study, TES allowed the acquisition of reads assigned to vertebrate viruses from all irrigation water samples, with the highest diversity observed in the Llobregat river water sample (LLRIV.1). Among the viruses identified in food samples, NoV GII sequences obtained from parsley, which showed a concentration of $7.12 \times 10^{1} \mathrm{GC} / 25 \mathrm{~g}$ by NoV GII qPCR, constituted a unique contig that was typed as NoV GII.17. This genotype emerged as a major cause of gastroenteritis outbreaks in China and Japan in the winter of 2014/2015 [89]. Interestingly, NoV GII sequences were not obtained from the strawberry sample STR1.1 using the capture approach despite it showing a high concentration of NoV GII in the specific qPCR assay. This result could be associated with differences in food matrices: detecting viruses in berries is known to be challenging due to the presence of various inhibitory substances and low $\mathrm{pH}$ [90]. Bartsch et al. also obtained a low number of $\mathrm{NoV}$ reads from the metagenomic analysis of frozen strawberries involved in a large NoV gastroenteritis outbreak [39]. The emergent genotype detected in parsley-NoV GII.17-was also sequenced from the Llobregat river, which also showed other sequences belonging to the Norwalk virus typed as NoV GI.1 and NoV GII.4.

ADS assays enabled a better characterization of the NoV diversity present in the studied fresh produce and irrigation water samples. This approach, based on the mass sequencing of traditionally Sanger-sequenced PCR amplicons, facilitates the detailed study of specific families and their diversity within a sample [21] and has previously been applied to environmental and shellfish samples for studying viral groups-such as Adenoviridae [21,65,91], Papillomaviridae [21,23,92,93], or NoVs [48,52,53]—but none of these studies investigated fresh food samples. Due to differences in the sensitivities of NoV assays and the fact that the concentrations detected were low, not all qPCR-positive samples were 
positive in RT-PCR amplification for ADS. In particular, STR1.1, PAR3.1, PAR3.2, and RIV3.1, which were qPCR-positive for NoV GII and qPCR-negative for NoV GI, produced an RT-PCR amplicon of the expected size for NoV GI but not for NoV GII. Additionally, groundwater and treated wastewater (WPFE) samples were positive for NoV GII in the qPCR assay, but no amplicons of the expected size were produced by conventional RT-PCR. This result may be explained by the lower sensitivity of this technique as compared to the qPCR assay [87,94]. In contrast, LET3.4 showed an amplicon of the expected size for NoV GI, although it did not show (or at least not above the limit of detection) NoV contamination by qPCR, which could be due to sensitivity differences between assays when concentrations are around this limit.

NoV GII.4 has been reported to be the most predominant genotype worldwide $[95,96]$. This is consistent with our findings, in which the presence of the GII.4 genotype was widely observed in different samples using ADS, including river water and treated wastewater samples, and also in a parsley sample. Llobregat river water was the sample with the highest number of sequences obtained from this specific genotype using ADS, and it was also the only sample in which this genotype was possible to sequence using TES. In fact, the three genotypes identified from the Llobregat river using TES, GI.1, GII.4, and GII.17, were also identified by ADS. It is important to highlight that all NoV genotypes found in food samples, GI.4 and GI.1 in strawberry and GI.4, GII.4, GII.13, and GII.2 in parsley, were also found in irrigation water samples. Maunula et al. also detected NoV GI.4 in frozen raspberries from one particular batch that was confirmed to be the source of a described cluster of NoV outbreaks affecting about 200 people in Southern Finland in 2009 [97].

In addition to viruses belonging to Caliciviridae, the TES results also showed other pathogenic or potentially pathogenic viruses present in river water, specifically viruses belonging to Astroviridae, Picornaviridae, and Parvoviridae families, which is consistent with the virome previously described in a river in the same geographical area that is also used for irrigation [5]. The Llobregat river contained a wide diversity of HAstVs, including the species Mamastrovirus 1, 6, and 8. HAstVs are important agents causing acute gastroenteritis in children and have been involved in outbreaks affecting adults $[95,98]$. Although HAstV prevalence seems to be of lower importance compared to the number of outbreaks caused by NoV, its importance might be underestimated [5]. Recently, HAstVs have also been associated with other pathologies, such as meningitis and acute flaccid paralysis [95,99-101]. HAstV-1, which was found in river water samples, is the most common type associated with infantile gastroenteritis [95,102]. Picornaviridae sequences found in river water samples belonged to the genus Kobuvirus, specifically to Aichivirus A, a viral species that includes members recognized as human pathogens that cause gastroenteritis outbreaks [103-105]. Other Picornaviridae sequences were assigned to Salivirus A, belonging to the genus Salivirus. The highest proportion of the vertebrate virus sequences obtained were human viruses, and among all types of irrigation water, the Llobregat river showed the highest number of reads and diversity of viruses that infect non-human vertebrates, including feline, canine, porcine, rodent, and cattle viruses belonging to Astroviridae, Caliciviridae, Parvoviridae, and Picornaviridae families. River water from Production Site 3 presented feline and porcine viruses designated as Astroviridae members. Among all vertebrate virus sequences obtained using TES, the greatest proportion of viruses that infect humans was observed, as expected, in treated wastewater, with human viruses accounting for all viruses detected in secondarytreated wastewater, and were identified as members belonging to Astroviridae, Circoviridae, Parvoviridae, and Picornaviridae, which is consistent with other metagenomic studies [22,106]. The non-human vertebrate viruses sequenced in treated wastewater were canine and cattle parvoviruses. Human viral sequences belonging to Circoviridae and Parvoviridae and avian, equine and bat viruses belonging to Genomoviridae and Parvoviridae were also detected in groundwater samples. Viruses are commonly detected in groundwater used for irrigation, even though it is often considered a microbially safe source $[7,107]$. These viruses may originate from the leakage of sewage water or diffuse contamination from livestock production zones close to produce fields [108]. In this study, the sequences 
obtained using TES assigned to viruses that infect non-human vertebrates of interest could be related to intensive farming activities in the surrounding areas, which have the potential to contaminate irrigation water through leakage. Despite lower yields of production in organic farming compared with intensive agriculture, organic farming systems represent an attractive environmentally friendly alternative, delivering equally or more nutritious foods that contain less, or no, pesticide residues [109]. This system relies on the incorporation of organic material into the soil using animal manure as fertilizer [110-112]. Although animal manure is considered a beneficial organic fertilizer and a good source of nutrients, it is also a well-known source of foodborne pathogenic bacteria, parasites, and viruses if it is not adequately aged or treated before application $[13,113,114]$ and, therefore, is a potential consumption risk.

Despite having samples positive for HAdV in the qPCR assay, no assignments belonging to Adenoviridae were obtained using TES. It has been previously reported that the SISPA protocol, which is performed prior to library preparation in order to overcome the limitation of low quantities of viral genomes, might introduce bias by amplifying the most abundant genomes and, therefore, underrepresenting others [115,116]. Fernández-Cassi et al. already noted these specific difficulties when detecting low numbers of dsDNA viruses such as HAdV in river water or when unable to detect HAdV in parsley samples that were positive for the virus in the qPCR assay [5]. Considering that TES did not allow the acquisition of HAdV sequences, a more suitable approach, such as ADS, should be applied to improve the sensitivity of viral metagenomics. Similarly, no sequences of Papillomaviridae were obtained from the TES approach. The detection of HPVs could also be affected by SISPA bias due to their dsDNA genome. However, ADS was demonstrated to be a suitable HPV detection and diversity exploration tool that overcomes this specific TES limitation since a wide variety of HPV was observed using this approach. Two different primer sets were used: GP5+/GP6+ were designed for detecting mucosal HPV types [79], whereas FAP6085/6319 were designed for detecting cutaneous HPV types [78]. The role of cutaneous HPV types in pathogenesis remains unclear: some are regarded as potential high-risk types because they are found in squamous cell carcinoma (SCC), such as HPV-5 or HPV-8, while most other cutaneous HPVs are only associated with benign lesions such as epidermodysplasia verruciformis $[117,118]$. Most of the HPV types sequenced in this study were classified as Betapapillomavirus. River and treated wastewater samples contained the highest diversity of Betapapillomavirus: HPV-12, HPV-17, HPV-37, HPV-38, HPV-76, HPV-92, HPV-96, HPV-105, HPV-122, HPV-145, and HPV-182. Treated wastewater also contained HPV-196 and HPV-8 sequences, the last of which is the HPV mostly found in SCC of the skin [117], and it has been described as an abundant HPV type in urban sewage [21]. HPV-12, HPV-37, HPV-38, HPV-76, HPV-92, HPV-105, HPV-122, and HPV-145 types were also identified in lettuce and parsley samples, and HPV-96 was only detected in lettuce. HPVs belonging to Alphapapillomavirus were also sequenced. HPV-177 was identified in river water and treated wastewater, as well as in lettuce and parsley samples. HPV-57 is associated with common warts typically occurring in the anogenital region [119] and was identified in river water, treated wastewater, and lettuce. Members belonging to the genus Alphapapillomavirus have been described previously in raw sewage [21,23]. HPV was frequently detected in the food and irrigation water samples analyzed in this study and should therefore be considered a potential emergent pathogen, and the role of irrigation water and fresh produce in the transmission of HPV should be further investigated. To our knowledge, this study is the first to provide data on the diversity of HPVs and NoVs present in fresh fruit and vegetable samples. Manipulation during the production process should not be ruled out as a route through which viral contamination is introduced to the food analyzed in this study. It is possible that some of the HPVs detected in food samples were skin contaminants, since most of the reads were classified as members belonging to the genus Betapapillomavirus, which includes types commonly isolated from skin. From sample collection to analysis, samples were handled carefully using gloves during all processes in order to avoid any kind of viral contamination. It is important to remark that 
all viruses detected in food were also detected in water samples, supporting the possibility that irrigation water is a source of contaminant HPVs.

The results of this study indicate that irrigation water and fresh fruits and vegetables present a wide variety of viral pathogens that may pose a risk to humans. Natural water treatments or disinfection procedures are often necessary to obtain high quality irrigation water. The implementation of quality monitoring programs integrated with Quantitative Microbial Risk Assessment (QMRA) investigations will provide an estimate of the level of risk and the treatments needed to produce high quality water. The NGS techniques described in this study would be useful for the identification of significant pathogens present in water and food for risk assessment studies, the selection of water treatments and the development of optimized site-specific safety plans. Because wastewater is usually of poor chemical and microbiological quality, extensive treatments are required before it can be safely used for irrigation [113]. However, drought conditions are linked to the utilization of untreated wastewater or contaminated groundwater for irrigation due to the lack of clean water, increasing the chances of microbial contamination of food products and soil [120]. In addition, due to climate change, unpredictable meteorological phenomena are expected to become more frequent and likely to drive an increase in the incidence of water scarcity with a probability of drought [1], potentially leading to the utilization of reclaimed water as a common source for irrigation in many locations. The association between pathogen diversity in this type of irrigation water and foodborne disease would imply that efficient treatments must be implemented to promote its use as an additional and safe water source. This study only suggests a possible link between irrigation water and the contamination origin of fresh produce, but other contamination factors involved in agricultural practices could certainly have an impact and should be considered, such as organic fertilizer or run-off from nearby animal pastures, which could also be vehicles for viral contamination $[85,121]$. Furthermore, detection of viral genomic sequences does not necessarily imply a consumption risk since infectivity potential was not verified in this study. In sum, irrigation water and animal manure are considered the two most important pathways of pathogen transmission from human or animal hosts to fresh produce at the preharvest level [10].

Checking for the presence of viruses as a part of controlling the quality of irrigation water is a key intervention step to reduce the risk of transferring contamination to fresh produce $[108,122]$. Further studies are needed to confirm and elucidate the significance of the information provided in terms of risk for consumption. From the data obtained in this study, we conclude that TES is a useful tool to obtain a broad picture of vertebrate viruses that integrate into the virome of irrigation water samples, whereas ADS allows the in-depth characterization of the diversity of a specific viral pathogen contaminating irrigation water and fresh produce. More relevant is that, by applying these methodologies, human pathogenic viruses were detected in samples in which qPCR showed low levels of contamination, suggesting that NGS approaches could be a suitable tool to identify and characterize viral pathogens and improve food monitoring and foodborne disease outbreak control.

\section{Conclusions}

- The fresh fruits and vegetables cultured in the analyzed organic farms show a high frequency of viral contamination, and the contaminating viruses are also detected in river water and tertiary effluents from subsurface water flow paths used in irrigation, indicating that they are common circulating pathogens.

- In this study, irrigation water is the most probable source of the viral pathogens, primarily NoV and HPV, detected in food. All pathogens were detected in some types of irrigation water, such as river water or treated wastewater, indicating that are potential sources of contamination. However, virus infectivity potential was not analyzed in this study. 
- A wide diversity of cutaneous HPV was detected in fresh produce and a wider diversity of HPV was identified in more polluted water samples, such as river and treated wastewater samples. HPV-8, a high-risk type associated with SCC, was found in treated wastewater.

- The three methodologies used for the analysis of viral contamination of irrigation water and organic food are useful and produce different types of information: (a) qPCR is a highly sensitive quantitative and specific technique, (b) TES shows the presence of relatively abundant viral pathogens present in irrigation water, including unexpected viral pathogens and potentially zoonotic strains, and (c) ADS provides higher sensitivity for the identification of viral types or variants in viral groups that contaminate food and water.

Supplementary Materials: The following are available online at https:/ / www.mdpi.com/article/10 .3390 / foods10081820/s1, Table S1: Quantification of viral pathogens in irrigation water and fresh produce samples. Values are expressed in GC/L for irrigation water samples and in GC/25 g for food samples. ND: Not Detected; Table S2: Reads obtained from each viral assignment in irrigation water, strawberry, lettuce, and parsley samples using target enrichment sequencing. Colors represent the specific host of vertebrate viruses, legend can be found under the table.

Author Contributions: Conceptualization, R.G., M.R., S.B.-M., S.M.-P. and M.I.; Methodology, M.I., R.G., S.M.-P., E.F., M.R. and A.H.; Software, S.M.-P., M.I. and N.T.; Validation, M.R., S.B.-M. and R.G.; Formal analysis, M.R., R.G., M.I., S.M.-P. and N.T.; Investigation, M.I. and M.R.; Resources, S.B.-M. and R.G.; Data curation, M.I., M.R., R.G. and S.B.-M.; Writing-original draft preparation, M.I., M.R. and R.G.; Writing-review and editing, M.I.; M.R., S.B.-M., S.M.-P., E.F., N.T., A.H. and R.G.; Visualization, M.I., M.R., S.M.-P. and S.B.-M.; Supervision, R.G. and M.R.; Project administration, M.R., S.B.-M. and R.G.; Funding acquisition, M.R., S.B.-M. and R.G. All authors have read and agreed to the published version of the manuscript.

Funding: This work was partially funded by a grant from the Spanish Ministry of Economy and Competitiveness (MINECO) AGL2017-86797-C2-1-R. IDEA-CSIC is a Centre of Excellence Severo Ochoa (Spanish Ministry of Science and Innovation (MICINN), Project CEX2018-000794-S).

Data Availability Statement: The datasets generated during the current study are available in Zenodo under the DOI number https:/ / doi.org/10.5281/zenodo.4722797.

Acknowledgments: Sílvia Bofill-Mas is a Serra-Hunter fellow at the University of Barcelona. Eva Forés is an APIF fellow at the University of Barcelona. Marta Itarte is a fellow of the Catalan Government "AGAUR" (FI) at the University of Barcelona.

Conflicts of Interest: The authors declare no conflict of interest.

\section{References}

1. Hess, T.; Sutcliffe, C. The Exposure of a Fresh Fruit and Vegetable Supply Chain to Global Water-Related Risks. Water Int. 2018, 43, 746-761. [CrossRef]

2. Balali, G.I.; Yar, D.D.; Afua Dela, V.G.; Adjei-Kusi, P. Microbial Contamination, an Increasing Threat to the Consumption of Fresh Fruits and Vegetables in Today's World. Int. J. Microbiol. 2020, 2020, 3029295. [CrossRef]

3. Septembre-Malaterre, A.; Remize, F.; Poucheret, P. Fruits and Vegetables, as a Source of Nutritional Compounds and Phytochemicals: Changes in Bioactive Compounds during Lactic Fermentation. Food Res. Int. 2018, 104, 86-99. [CrossRef] [PubMed]

4. Mir, S.A.; Shah, M.A.; Mir, M.M.; Dar, B.N.; Greiner, R.; Roohinejad, S. Microbiological Contamination of Ready-to-Eat Vegetable Salads in Developing Countries and Potential Solutions in the Supply Chain to Control Microbial Pathogens. Food Control 2018, 85, 235-244. [CrossRef]

5. Fernandez-Cassi, X.; Timoneda, N.; Gonzales-Gustavson, E.; Abril, J.F.; Bofill-Mas, S.; Girones, R. A Metagenomic Assessment of Viral Contamination on Fresh Parsley Plants Irrigated with Fecally Tainted River Water. Int. J. Food Microbiol. 2017, 257, 80-90. [CrossRef] [PubMed]

6. Callejón, R.M.; Rodríguez-Naranjo, M.I.; Ubeda, C.; Hornedo-Ortega, R.; Garcia-Parrilla, M.C.; Troncoso, A.M. Reported Foodborne Outbreaks Due to Fresh Produce in the United States and European Union: Trends and Causes. Foodborne Pathog. Dis. 2015, 12, 32-38. [CrossRef]

7. Shaheen, M.N.F.; Elmahdy, E.M.; Chawla-Sarkar, M. Quantitative PCR-Based Identification of Enteric Viruses Contaminating Fresh Produce and Surface Water Used for Irrigation in Egypt. Environ. Sci. Pollut. Res. 2019, 26, 21619-21628. [CrossRef] 
8. Iwu, C.D.; Okoh, A.I. Preharvest Transmission Routes of Fresh Produce Associated Bacterial Pathogens with Outbreak Potentials: A Review. Int. J. Environ. Res. Public Health 2019, 16, 4407. [CrossRef]

9. Garcia, B.C.B.; Dimasupil, M.A.A.Z.; Vital, P.G.; Widmer, K.W.; Rivera, W.L. Fecal Contamination in Irrigation Water and Microbial Quality of Vegetable Primary Production in Urban Farms of Metro Manila, Philippines. J. Environ. Sci. Health 2015, 50, 734-743. [CrossRef]

10. Park, S.; Szonyi, B.; Gautam, R.; Nightingale, K.; Anciso, J.; Ivanek, R. Risk Factors for Microbial Contamination in Fruits and Vegetables at the Preharvest Level: A Systematic Review. J. Food Prot. 2012, 75, 2055-2081. [CrossRef]

11. Wei, X.; Hou, S.; Pan, X.; Xu, C.; Li, J.; Yu, H.; Chase, J.; Atwill, E.R.; Li, X.; Chen, K.; et al. Microbiological Contamination of Strawberries from U-Pick Farms in Guangzhou, China. Int. J. Environ. Res. Public Health 2019, 16, 4910. [CrossRef]

12. Rodrigues, C.; da Silva, A.L.B.R.; Dunn, L.L. Factors Impacting the Prevalence of Foodborne Pathogens in Agricultural Water Sources in the Southeastern United States. Water 2020, 12, 51. [CrossRef]

13. Gil, M.I.; Selma, M.V.; Suslow, T.; Jacxsens, L.; Uyttendaele, M.; Allende, A. Pre- and Postharvest Preventive Measures and Intervention Strategies to Control Microbial Food Safety Hazards of Fresh Leafy Vegetables. Crit. Rev. Food Sci. Nutr. 2015, 55, 453-468. [CrossRef] [PubMed]

14. Pachepsky, Y.; Shelton, D.R.; McLain, J.E.T.; Patel, J.; Mandrell, R.E. Irrigation Waters as a Source of Pathogenic Microorganisms in Produce. A Review. Adv. Agron. 2011, 113, 73-138. [CrossRef]

15. Machado-Moreira, B.; Richards, K.; Brennan, F.; Abram, F.; Burgess, C.M. Microbial Contamination of Fresh Produce: What, Where, and How? Compr. Rev. Food Sci. Food Saf. 2019, 18, 1727-1750. [CrossRef]

16. Gobeil, A.; Maherani, B.; Lacroix, M. Norovirus Elimination on the Surface of Fresh Foods. Crit. Rev. Food Sci. Nutr. 2020. [CrossRef]

17. Gonzales-Gustavson, E.; Rusiñol, M.; Medema, G.; Calvo, M.; Girones, R. Quantitative Risk Assessment of Norovirus and Adenovirus for the Use of Reclaimed Water to Irrigate Lettuce in Catalonia. Water Res. 2019, 153, 91-99. [CrossRef] [PubMed]

18. Dicaprio, E.; Purgianto, A.; Li, J. Effects of Abiotic and Biotic Stresses on the Internalization and Dissemination of Human Norovirus Surrogates in Growing Romaine. Appl. Environ. Microbiol. 2015, 81, 4791-4800. [CrossRef] [PubMed]

19. Koo, H.L.; Ajami, N.; Atmar, R.L.; DuPont, H.L. Noroviruses: The Leading Cause of Gastroenteritis Worldwide. Discov. Med. 2010, 10, 61-70.

20. Newell, D.G.; Koopmans, M.; Verhoef, L.; Duizer, E.; Aidara-Kane, A.; Sprong, H.; Opsteegh, M.; Langelaar, M.; Threfall, J.; Scheutz, F.; et al. Food-Borne Diseases-The Challenges of 20 Years Ago Still Persist While New Ones Continue to Emerge. Int. J. Food Microbiol. 2010, 139, S3-S15. [CrossRef]

21. Martínez-Puchol, S.; Rusiñol, M.; Fernández-Cassi, X.; Timoneda, N.; Itarte, M.; Andrés, C.; Antón, A.; Abril, J.F.; Girones, R.; Bofill-Mas, S. Characterisation of the Sewage Virome: Comparison of NGS Tools and Occurrence of Significant Pathogens. Sci. Total Environ. 2020, 713, 136604. [CrossRef]

22. Rusiñol, M.; Martínez-Puchol, S.; Timoneda, N.; Fernández-Cassi, X.; Pérez-Cataluña, A.; Fernández-Bravo, A.; Moreno-Mesonero, L.; Moreno, Y.; Alonso, J.L.; Figueras, M.J.; et al. Metagenomic Analysis of Viruses, Bacteria and Protozoa in Irrigation Water. Int. J. Hyg. Environ. Health 2020, 224, 113440. [CrossRef] [PubMed]

23. Iaconelli, M.; Petricca, S.; Della Libera, S.; Di Bonito, P.; La Rosa, G. First Detection of Human Papillomaviruses and Human Polyomaviruses in River Waters in Italy. Food Environ. Virol. 2015, 7, 309-315. [CrossRef]

24. La Rosa, G.; Fratini, M.; Accardi, L.; D’Oro, G.; Della Libera, S.; Muscillo, M.; Di Bonito, P. Mucosal and Cutaneous Human Papillomaviruses Detected in Raw Sewages. PLoS ONE 2013, 8, e52391. [CrossRef]

25. Di Bonito, P.; Della Libera, S.; Petricca, S.; Iaconelli, M.; Sanguinetti, M.; Graffeo, R.; Accardi, L.; La Rosa, G. A Large Spectrum of Alpha and Beta Papillomaviruses Are Detected in Human Stool Samples. J. Gen. Virol. 2015, 96, 607-613. [CrossRef] [PubMed]

26. Di Cola, G.; Fantilli, A.C.; Pisano, M.B.; Ré, V.E. Foodborne Transmission of Hepatitis A and Hepatitis E Viruses: A Literature Review. Int. J. Food Microbiol. 2021, 338, 108986. [CrossRef] [PubMed]

27. EFSA BIOHAZ Panel. Scientific Opinion on the Guidance on the Requirements for the Development of Microbiological Criteria. EFSA J. 2017, 15, 5052. [CrossRef]

28. EU C163. Guidance Document on Addressing Microbiological Risks in Fresh Fruits and Vegetables at Primary Production through Good Hygiene. Off. J. Eur. Union. 2017, 163, 1-40.

29. Rusiñol, M.; Hundesa, A.; Cárdenas-Youngs, Y.; Fernández-Bravo, A.; Pérez-Cataluña, A.; Moreno-Mesonero, L.; Moreno, Y.; Calvo, M.; Alonso, J.L.; Figueras, M.J.; et al. Microbiological Contamination of Conventional and Reclaimed Irrigation Water: Evaluation and Management Measures. Sci. Total Environ. 2020, 710, 136298. [CrossRef] [PubMed]

30. Girones, R.; Ferrús, M.A.; Alonso, J.L.; Rodriguez-Manzano, J.; Calgua, B.; de Abreu Corrêa, A.; Hundesa, A.; Carratala, A.; Bofill-Mas, S. Molecular Detection of Pathogens in Water-The Pros and Cons of Molecular Techniques. Water Res. 2010, 44, 4325-4339. [CrossRef]

31. Gerba, C.P.; Goyal, S.M.; LaBelle, R.L.; Bodgan, G.F. Failure of Indicator Bacteria to Reflect the Occurrence of Enteroviruses in Marine Waters. Am. J. Public Health 1979, 69, 1116-1119. [CrossRef]

32. Pusch, D.; Oh, D.Y.; Wolf, S.; Dumke, R.; Schröter-Bobsin, U.; Höhne, M.; Röske, I.; Schreier, E. Detection of Enteric Viruses and Bacterial Indicators in German Environmental Waters. Arch. Virol. 2005, 150, 929-947. [CrossRef] [PubMed] 
33. Savichtcheva, O;; Okabe, S. Alternative Indicators of Fecal Pollution: Relations with Pathogens and Conventional Indicators, Current Methodologies for Direct Pathogen Monitoring and Future Application Perspectives. Water Res. 2006, 40, $2463-2476$. [CrossRef] [PubMed]

34. Allard, A.; Vantarakis, A. Adenoviruses. Glob. Water Pathog. Proj. 2017. [CrossRef]

35. Verani, M.; Federigi, I.; Donzelli, G.; Cioni, L.; Carducci, A. Human Adenoviruses as Waterborne Index Pathogens and Their Use for Quantitative Microbial Risk Assessment. Sci. Total Environ. 2019, 651, 1469-1475. [CrossRef] [PubMed]

36. Hewitt, J.; Greening, G.E.; Leonard, M.; Lewis, G.D. Evaluation of Human Adenovirus and Human Polyomavirus as Indicators of Human Sewage Contamination in the Aquatic Environment. Water Res. 2013, 47, 6750-6761. [CrossRef]

37. Albinana-Gimenez, N.; Miagostovich, M.P.; Calgua, B.; Huguet, J.M.; Matia, L.; Girones, R. Analysis of Adenoviruses and Polyomaviruses Quantified by QPCR as Indicators of Water Quality in Source and Drinking-Water Treatment Plants. Water Res. 2009, 43, 2011-2019. [CrossRef]

38. International Organization for Standardization. ISO 15216-1. Microbiology of the Food Chain-Horizontal Method for Determination of Hepatitis A Virus and Norovirus in Food Using Real-Time RT-PCR-Part 1: Method for Quantification. Available online: https: / / www.iso.org/standard/65681.html (accessed on 8 April 2021).

39. Bartsch, C.; Höper, D.; Mäde, D.; Johne, R. Analysis of Frozen Strawberries Involved in a Large Norovirus Gastroenteritis Outbreak Using Next Generation Sequencing and Digital PCR. J. Food Microbiol. 2018, 76, 390-395. [CrossRef] [PubMed]

40. Mäde, D.; Trübner, K.; Neubert, E.; Höhne, M.; Johne, R. Detection and Typing of Norovirus from Frozen Strawberries Involved in a Large-Scale Gastroenteritis Outbreak in Germany. Food Environ. Virol. 2013, 5, 162-168. [CrossRef] [PubMed]

41. Schrader, C.; Schielke, A.; Ellerbroek, L.; Johne, R. PCR Inhibitors-Occurrence, Properties and Removal. J. Appl. Microbiol. 2012, 113, 1014-1026. [CrossRef]

42. Scherer, K.; Johne, R.; Schrader, C.; Ellerbroek, L.; Schulenburg, J.; Klein, G. Comparison of Two Extraction Methods for Viruses in Food and Application in a Norovirus Gastroenteritis Outbreak. J. Virol. Methods 2010, 169, 22-27. [CrossRef]

43. Aw, T.G.; Wengert, S.; Rose, J.B. Metagenomic Analysis of Viruses Associated with Field-Grown and Retail Lettuce Identifies Human and Animal Viruses. Int. J. Food Microbiol. 2016, 223, 50-56. [CrossRef] [PubMed]

44. Park, E.J.; Kim, K.H.; Abell GC, J.; Kim, M.S.; Roh, S.W.; Bae, J.W. Metagenomic Analysis of the Viral Communities in Fermented Foods. Appl. Environ. Microbiol. 2011, 77, 1284-1291. [CrossRef] [PubMed]

45. Zhang, W.; Li, L.; Deng, X.; Kapusinszky, B.; Delwart, E. What Is for Dinner? Viral Metagenomics of US Store Bought Beef, Pork, and Chicken. Virology 2014, 468-470, 303-310. [CrossRef]

46. Nieuwenhuijse, D.F.; Koopmans, M.P.G. Metagenomic Sequencing for Surveillance of Food- and Waterborne Viral Diseases. Front Microbiol. 2017, 8, 230. [CrossRef]

47. Aarestrup, F.M.; Brown, E.W.; Detter, C.; Gerner-Smidt, P.; Gilmour, M.W.; Harmsen, D.; Hendriksen, R.S.; Hewson, R.; Heymann, D.L.; Johansson, K.; et al. Integrating Genome-Based Informatics to Modernize Global Disease Monitoring, Information Sharing, and Response. Emerg. Infect. Dis. 2012, 18. [CrossRef]

48. Desdouits, M.; Wacrenier, C.; Ollivier, J.; Schaeffer, J.; Le Guyader, F.S. A Targeted Metagenomics Approach to Study the Diversity of Norovirus GII in Shellfish Implicated in Outbreaks. Viruses 2020, 12, 978. [CrossRef] [PubMed]

49. Filipa-Silva, A.; Parreira, R.; Martínez-Puchol, S.; Bofill-Mas, S.; Barreto Crespo, M.T.; Nunes, M. The Unexplored Virome of Two Atlantic Coast Fish: Contribution of Next-Generation Sequencing to Fish Virology. Foods 2020, 9, 1634. [CrossRef] [PubMed]

50. Strubbia, S.; Schaeffer, J.; Besnard, A.; Wacrenier, C.; Le Mennec, C.; Garry, P.; Desdouits, M.; Le Guyader, F.S. Metagenomic to Evaluate Norovirus Genomic Diversity in Oysters: Impact on Hexamer Selection and Targeted Capture-Based Enrichment. Int. J. Food Microbiol. 2020, 323, 108588. [CrossRef]

51. Rosani, U.; Shapiro, M.; Venier, P.; Allam, B. A Needle in a Haystack: Tracing Bivalve-Associated Viruses in High-Throughput Transcriptomic Data. Viruses 2019, 11, 205. [CrossRef]

52. Oshiki, M.; Miura, T.; Kazama, S.; Segawa, T.; Ishii, S.; Hatamoto, M.; Yamaguchi, T.; Kubota, K.; Iguchi, A.; Tagawa, T.; et al. Microfluidic PCR Amplification and MiSeq Amplicon Sequencing Techniques for High-Throughput Detection and Genotyping of Human Pathogenic RNA Viruses in Human Feces, Sewage, and Oysters. Front. Microbiol. 2018, 9, 830. [CrossRef]

53. Imamura, S.; Kanezashi, H.; Goshima, T.; Haruna, M.; Okada, T.; Inagaki, N.; Uema, M.; Noda, M.; Akimoto, K. Next-Generation Sequencing Analysis of the Diversity of Human Noroviruses in Japanese Oysters. Foodborne Pathog. Dis. 2017, 14, 465-471. [CrossRef] [PubMed]

54. Chiapponi, C.; Pavoni, E.; Bertasi, B.; Baioni, L.; Scaltriti, E.; Chiesa, E.; Cianti, L.; Losio, M.N.; Pongolini, S. Isolation and Genomic Sequence of Hepatitis A Virus from Mixed Frozen Berries in Italy. Food Environ. Virol. 2014, 6, 202-206. [CrossRef] [PubMed]

55. Yang, Z.; Mammel, M.; Papafragkou, E.; Hida, K.; Elkins, C.A.; Kulka, M. Application of Next Generation Sequencing toward Sensitive Detection of Enteric Viruses Isolated from Celery Samples as an Example of Produce. Int. J. Food Microbiol. 2017, 261, 73-81. [CrossRef] [PubMed]

56. Toscano, A.; Marzo, A.; Milani, M.; Cirelli, G.L.; Barbagallo, S. Comparison of Removal Efficiencies in Mediterranean Pilot Constructed Wetlands Vegetated with Different Plant Species. Ecol. Eng. 2015, 75, 155-160. [CrossRef]

57. Ribot, M.; Bernal, S.; Nikolakopoulou, M.; Vaessen, T.N.; Cochero, J.; Gacia, E.; Sorolla, A.; Argerich, A.; Sabater, F.; Isnard, M.; et al. Enhancement of Carbon and Nitrogen Removal by Helophytes along Subsurface Water Flowpaths Receiving Treated Wastewater. Sci. Total Environ. 2017, 599-600, 1667-1676. [CrossRef] 
58. Bofill-Mas, S.; Albinana-Gimenez, N.; Clemente-Casares, P.; Hundesa, A.; Rodriguez-Manzano, J.; Allard, A.; Calvo, M.; Girones, R. Quantification and Stability of Human Adenoviruses and Polyomavirus JCPyV in Wastewater Matrices. Appl. Environ. Microbiol. 2006, 72, 7894-7896. [CrossRef]

59. Da Silva, A.K.; Le Saux, J.C.; Parnaudeau, S.; Pommepuy, M.; Elimelech, M.; Le Guyader, F.S. Evaluation of Removal of Noroviruses during Wastewater Treatment, Using Real-Time Reverse Transcription-PCR: Different Behaviors of Genogroups I and II. Appl. Environ. Microbiol. 2007, 73, 7891-7897. [CrossRef] [PubMed]

60. Svraka, S.; Duizer, E.; Vennema, H.; De Bruin, E.; Van Der Veer, B.; Dorresteijn, B.; Koopmans, M. Etiological Role of Viruses in Outbreaks of Acute Gastroenteritis in The Netherlands from 1994 through 2005. J. Clin. Microbiol. 2007, 45, 1389-1394. [CrossRef]

61. Hoehne, M.; Schreier, E. Detection of Norovirus Genogroup I and II by Multiplex Real-Time RT-PCR Using a 3'-Minor Groove Binder-DNA Probe. BMC Infect. Dis. 2006, 6, 69. [CrossRef] [PubMed]

62. Loisy, F.; Atmar, R.L.; Guillon, P.; Le Cann, P.; Pommepuy, M.; Le Guyader, F.S. Real-Time RT-PCR for Norovirus Screening in Shellfish. J. Virol. Methods 2005, 123, 1-7. [CrossRef]

63. Kageyama, T.; Kojima, S.; Shinohara, M.; Uchida, K.; Fukushi, S.; Hoshino, F.B.; Takeda, N.; Katayama, K. Broadly Reactive and Highly Sensitive Assay for Norwalk-like Viruses Based on Real-Time Quantitative Reverse Transcription-PCR. J. Clin. Microbiol. 2003, 41, 1548-1557. [CrossRef]

64. Jothikumar, N.; Cromeans, T.L.; Robertson, B.H.; Meng, X.J.; Hill, V.R. A Broadly Reactive One-Step Real-Time RT-PCR Assay for Rapid and Sensitive Detection of Hepatitis E Virus. J. Virol. Methods 2006, 131, 65-71. [CrossRef]

65. Fernandez-Cassi, X.; Timoneda, N.; Martínez-Puchol, S.; Rusiñol, M.; Rodriguez-Manzano, J.; Figuerola, N.; Bofill-Mas, S.; Abril, J.F.; Girones, R. Metagenomics for the Study of Viruses in Urban Sewage as a Tool for Public Health Surveillance. Sci. Total. Environ. 2018, 618, 870-880. [CrossRef]

66. Fernandez-Cassi, X.; Rusiñol, M.; Martínez-Puchol, S. Viral Concentration and Amplification from Human Serum Samples Prior to Application of Next-Generation Sequencing Analysis. Methods Mol. Biol. 2018, 1838, 173-188. [CrossRef] [PubMed]

67. Hjelmsø, M.H.; Mollerup, S.; Jensen, R.H.; Pietroni, C.; Lukjancenko, O.; Schultz, A.C.; Aarestrup, F.M.; Hansen, A.J. Metagenomic Analysis of Viruses in Toilet Waste from Long Distance Flights-A New Procedure for Global Infectious Disease Surveillance. PLoS ONE 2019, 14, e0210368. [CrossRef]

68. Briese, T.; Kapoor, A.; Mishra, N.; Jain, K.; Kumar, A.; Jabado, O.J.; Ian Lipkina, W. Virome Capture Sequencing Enables Sensitive Viral Diagnosis and Comprehensive Virome Analysis. MBio 2015, 6, e01491-15. [CrossRef] [PubMed]

69. Vilsker, M.; Moosa, Y.; Nooij, S.; Fonseca, V.; Ghysens, Y.; Dumon, K.; Pauwels, R.; Alcantara, L.C.; Vanden Eynden, E.; Vandamme, A.-M.; et al. Genome Detective: An Automated System for Virus Identification from High-Throughput Sequencing Data. Bioinformatics 2019, 35, 871-873. [CrossRef] [PubMed]

70. Benson, D.A.; Clark, K.; Karsch-Mizrachi, I.; Lipman, D.J.; Ostell, J.; Sayers, E.W. GenBank. Nucleic Acids Res. 2015, 43, D30-D35. [CrossRef]

71. Altschul, S.F.; Gish, W.; Miller, W.; Myers, E.W.; Lipman, D.J. Basic Local Alignment Search Tool. J. Mol. Biol. 1990, 215 , 403-410. [CrossRef]

72. Kearse, M.; Moir, R.; Wilson, A.; Stones-Havas, S.; Cheung, M.; Sturrock, S.; Buxton, S.; Cooper, A.; Markowitz, S.; Duran, C.; et al. Geneious Basic: An Integrated and Extendable Desktop Software Platform for the Organization and Analysis of Sequence Data. Bioinformatics 2012, 28, 1647-1649. [CrossRef]

73. Chhabra, P.; de Graaf, M.; Parra, G.I.; Chan, M.C.W.; Green, K.; Martella, V.; Wang, Q.; White, P.A.; Katayama, K.; Vennema, H.; et al. Updated Classification of Norovirus Genogroups and Genotypes. J. Gen. Virol. 2019, 100, 1393-1406. [CrossRef]

74. Chhabra, P.; de Graaf, M.; Parra, G.I.; Chan, M.C.W.; Green, K.; Martella, V.; Wang, Q.; White, P.A.; Katayama, K.; Vennema, H.; et al. Corrigendum: Updated Classification of Norovirus Genogroups and Genotypes. J. Gen. Virol. 2020, 101, 893. [CrossRef]

75. Kroneman, A.; Vennema, H.; Deforche, K.; Avoort, H.; Peñaranda, S.; Oberste, M.S.; Vinjé, J.; Koopmans, M. An Automated Genotyping Tool for Enteroviruses and Noroviruses. J. Clin. Virol. 2011, 51, 121-125. [CrossRef]

76. Kitajima, M.; Oka, T.; Haramoto, E.; Takeda, N.; Katayama, K.; Katayama, H. Seasonal Distribution and Genetic Diversity of Genogroups I, II, and IV Noroviruses in the Tamagawa River, Japan. Environ. Sci. Technol. 2010, 44, 7116-7122. [CrossRef]

77. Aw, T.G.; Gin, K.Y.H.; Oon, L.L.E.; Chen, E.X.; Woo, C.H. Prevalence and Genotypes of Human Noroviruses in Tropical Urban Surface Waters and Clinical Samples in Singapore. Appl. Environ. Microbiol. 2009, 75, 4984-4992. [CrossRef]

78. Forslund, O.; Ly, H.; Higgins, G. Improved Detection of Cutaneous Human Papillomavirus DNA by Single Tube Nested “hanging Droplet" PCR. J. Virol. Methods 2003, 110, 129-136. [CrossRef]

79. De Roda Husman, A.M.; Walboomers, J.M.M.; Van den Brule, A.J.C.; Meijer, C.J.L.M.; Snijders, P.J.F. The Use of General Primers GP5 and GP6 Elongated at Their 3' Ends with Adjacent Highly Conserved Sequences Improves Human Papillomavirus Detection by PCR. J. Gen. Virol. 1995, 76, 1057-1062. [CrossRef] [PubMed]

80. Bofill-Mas, S.; Rusiñol, M.; Fernandez-Cassi, X.; Carratalà, A.; Hundesa, A.; Girones, R. Quantification of Human and Animal Viruses to Differentiate the Origin of the Fecal Contamination Present in Environmental Samples. Biomed. Res. Int. 2013 , 2013. [CrossRef] [PubMed]

81. Rusiñol, M.; Fernandez-Cassi, X.; Hundesa, A.; Vieira, C.; Kern, A.; Eriksson, I.; Ziros, P.; Kay, D.; Miagostovich, M.; Vargha, M.; et al. Application of Human and Animal Viral Microbial Source Tracking Tools in Fresh and Marine Waters from Five Different Geographical Areas. Water Res. 2014, 59, 119-129. [CrossRef]

82. Rusiñol, M.; Girones, R. Summary of Excreted and Waterborne Viruses. Glob. Water Pathog. Proj. 2017. [CrossRef] 
83. Vieira, C.B.; de Abreu Corrêa, A.; de Jesus, M.S.; Luz, S.L.B.; Wyn-Jones, P.; Kay, D.; Vargha, M.; Miagostovich, M.P. Viruses Surveillance Under Different Season Scenarios of the Negro River Basin, Amazonia, Brazil. Food Environ. Virol. 2016, 8, 57-69. [CrossRef] [PubMed]

84. Kokkinos, P.; Kozyra, I.; Lazic, S.; Bouwknegt, M.; Rutjes, S.; Willems, K.; Moloney, R.; de Roda Husman, A.M.; Kaupke, A.; Legaki, E.; et al. Harmonised Investigation of the Occurrence of Human Enteric Viruses in the Leafy Green Vegetable Supply Chain in Three European Countries. Food Environ. Virol. 2012, 4, 179-191. [CrossRef]

85. Maunula, L.; Kaupke, A.; Vasickova, P.; Söderberg, K.; Kozyra, I.; Lazic, S.; van der Poel, W.H.M.; Bouwknegt, M.; Rutjes, S.; Willems, K.A.; et al. Tracing Enteric Viruses in the European Berry Fruit Supply Chain. Int. J. Food Microbiol. 2013, 167, 177-185. [CrossRef] [PubMed]

86. Brassard, J.; Gagné, M.; Généreux, M.; Côté, C. Detection of Human Food-Borne and Zoonotic Viruses on Irrigated, Field-Grown Strawberries. Appl. Environ. Microbiol. 2012, 78, 3763-3766. [CrossRef] [PubMed]

87. Baert, L.; Mattison, K.; Loisy-Hamon, F.; Harlow, J.; Martyres, A.; Lebeau, B.; Stals, A.; Van Coillie, E.; Herman, L.; Uyttendaele, M. Review: Norovirus Prevalence in Belgian, Canadian and French Fresh Produce: A Threat to Human Health? Int. J. Food Microbiol. 2011, 151, 261-269. [CrossRef]

88. Cantalupo, P.G.; Calgua, B.; Zhao, G.; Hundesa, A.; Wier, A.D.; Katz, J.P.; Grabe, M.; Hendrix, R.W.; Girones, R.; Wang, D.; et al. Raw Sewage Harbors Diverse Viral Populations. MBio 2011, 2, e00180. [CrossRef]

89. De Graaf, M.; Van Beek, J.; Vennema, H.; Podkolzin, A.T.; Hewitt, J.; Bucardo, F.; Templeton, K.; Mans, J.; Nordgren, J.; Reuter, G.; et al. Emergence of a Novel GII.17 Norovirus-End of the GII.4 Era? Eurosurveillance 2015, 20, 21178. [CrossRef]

90. Le Guyader, F.S.; Mittelholzer, C.; Haugarreau, L.; Hedlund, K.O.; Alsterlund, R.; Pommepuy, M.; Svensson, L. Detection of Noroviruses in Raspberries Associated with a Gastroenteritis Outbreak. Int. J. Food Microbiol. 2004, 97, 179-186. [CrossRef]

91. Ogorzaly, L.; Walczak, C.; Galloux, M.; Etienne, S.; Gassilloud, B.; Cauchie, H.M. Human Adenovirus Diversity in Water Samples Using a Next-Generation Amplicon Sequencing Approach. Food Environ. Virol. 2015, 7, 112-121. [CrossRef]

92. Hamza, H.; Hamza, I.A. Oncogenic Papillomavirus and Polyomavirus in Urban Sewage in Egypt. Sci. Total Environ. 2018, 610-611, 1413-1420. [CrossRef]

93. La Rosa, G.; Della Libera, S.; Petricca, S.; Iaconelli, M.; Briancesco, R.; Paradiso, R.; Semproni, M.; di Bonito, P.; Bonadonna, L. First Detection of Papillomaviruses and Polyomaviruses in Swimming Pool Waters: Unrecognized Recreational Water-Related Pathogens? J. Appl. Microbiol. 2015, 119, 1683-1691. [CrossRef]

94. Houde, A.; Leblanc, D.; Poitras, E.; Ward, P.; Brassard, J.; Simard, C.; Trottier, Y.L. Comparative Evaluation of RT-PCR, Nucleic Acid Sequence-Based Amplification (NASBA) and Real-Time RT-PCR for Detection of Noroviruses in Fecal Material. J. Virol. Methods 2006, 135, 163-172. [CrossRef] [PubMed]

95. Fernandez-Cassi, X.; Martínez-Puchol, S.; Silva-Sales, M.; Cornejo, T.; Bartolome, R.; Bofill-Mas, S.; Girones, R. Unveiling Viruses Associated with Gastroenteritis Using a Metagenomics Approach. Viruses 2020, 12, 1432. [CrossRef] [PubMed]

96. Tohma, K.; Lepore, C.J.; Gao, Y.; Ford-Siltz, L.A.; Parra, G.I. Population Genomics of GII.4 Noroviruses Reveal Complex Diversification and New Antigenic Sites Involved in the Emergence of Pandemic Strains. MBio 2019, 10, e02202-19. [CrossRef]

97. Maunula, L.; Roivainen, M.; Keränen, M.; Mäkela, S.; Söderberg, K.; Summa, M.; von Bonsdorff, C.H.; Lappalainen, M.; Korhonen, T.; Kuusi, M.; et al. Detection of Human Norovirus from Frozen Raspberries in a Cluster of Gastroenteritis Outbreaks. Eurosurveillance 2009, 14, 19435. [CrossRef] [PubMed]

98. Jeong, H.S.; Jeong, A.; Cheon, D.S. Epidemiology of Astrovirus Infection in Children. Korean J. Pediatr. 2012, 55, 77-82. [CrossRef] [PubMed]

99. Johnson, C.; Hargest, V.; Cortez, V.; Meliopoulos, V.A.; Schultz-Cherry, S. Astrovirus Pathogenesis. Viruses 2017, 9, 22. [CrossRef]

100. Cordey, S.; Vu, D.L.; Schibler, M.; L'Huillier, A.G.; Brito, F.; Docquier, M.; Posfay-Barbe, K.M.; Petty, T.J.; Turin, L.; Zdobnov, E.M.; et al. Astrovirus MLB2, a New Gastroenteric Virus Associated with Meningitis and Disseminated Infection. Emerg. Infect. Dis. 2016, 22, 846-853. [CrossRef]

101. Kapoor, A.; Li, L.; Victoria, J.; Oderinde, B.; Mason, C.; Pandey, P.; Zaidi, S.Z.; Delwart, E. Multiple Novel Astrovirus Species in Human Stool. J. Gen. Virol. 2009, 90, 2965-2972. [CrossRef]

102. Gabbay, Y.B.; Leite, J.P.G.; Oliveira, D.S.; Nakamura, L.S.; Nunes, M.R.T.; Mascarenhas, J.D.A.P.; Heinemann, M.B.; Linhares, A.C. Molecular Epidemiology of Astrovirus Type 1 in Belém, Brazil, as an Agent of Infantile Gastroenteritis, over a Period of 18 Years (1982-2000): Identification of Two Possible New Lineages. Virus Res. 2007, 129, 166-174. [CrossRef]

103. Rivadulla, E.; Romalde, J.L. A Comprehensive Review on Human Aichi Virus. Virol. Sin. 2020, 35, 501-516. [CrossRef] [PubMed]

104. Reuter, G.; Boros, Á.; Pankovics, P. Kobuviruses-A Comprehensive Review. Rev. Med. Virol. 2011, 21, 32-41. [CrossRef]

105. Ambert-Balay, K.; Lorrot, M.; Bon, F.; Giraudon, H.; Kaplon, J.; Wolfer, M.; Lebon, P.; Gendrel, D.; Pothier, P. Prevalence and Genetic Diversity of Aichi Virus Strains in Stool Samples from Community and Hospitalized Patients. J. Clin. Microbiol. 2008, 46, 1252-1258. [CrossRef]

106. Rosario, K.; Nilsson, C.; Lim, Y.W.; Ruan, Y.; Breitbart, M. Metagenomic Analysis of Viruses in Reclaimed Water. Environ. Microbiol. 2009, 11, 2806-2820. [CrossRef] [PubMed]

107. Gerba, C.P.; Choi, C.Y. Role of Irrigation Water in Crop Contamination by Viruses. In Viruses in Foods; Springer: Boston, MA, USA, 2006; pp. 257-263. [CrossRef]

108. Wei, J.; Jin, Y.; Sims, T.; Kniel, K.E. Internalization of Murine Norovirus 1 by Lactuca Sativa during Irrigation. Appl. Environ. Microbiol. 2011, 77, 2508-2512. [CrossRef] [PubMed] 
109. Reganold, J.P.; Wachter, J.M. Organic Agriculture in the Twenty-First Century. Nat. Plants 2016, 2, 15221. [CrossRef]

110. Machado, D.C.; Maia, C.M.; Carvalho, I.D.; Da Silva, N.F.; Dantas Porfírio Borges Andre, M.C.; Serafini, Á.B. Microbiological Quality of Organic Vegetables Produced in Soil Treated with Different Types of Manure and Mineral Fertilizer. Brazilian J. Microbiol. 2006, 37, 538-544. [CrossRef]

111. Grusenmeyer, D.C.; Cramer, T.N. Symposium: Manure Management. J. Dairy Sci. 1997, 80, 2651-2654. [CrossRef]

112. Pell, A.N. Manure and Microbes: Public and Animal Health Problem? J. Dairy Sci. 1997, 80, 2673-2681. [CrossRef]

113. Alegbeleye, O.O.; Singleton, I.; Sant'Ana, A.S. Sources and Contamination Routes of Microbial Pathogens to Fresh Produce during Field Cultivation: A Review. Food Microbiol. 2018, 73, 177-208. [CrossRef]

114. Mawdsley, J.L.; Bardgett, R.D.; Merry, R.J.; Pain, B.F.; Theodorou, M.K. Pathogens in Livestock Waste, Their Potential for Movement through Soil and Environmental Pollution. Appl. Soil Ecol. 1995, 2, 1-15. [CrossRef]

115. Duhaime, M.B.; Deng, L.; Poulos, B.T.; Sullivan, M.B. Towards Quantitative Metagenomics of Wild Viruses and Other Ultra-Low Concentration DNA Samples: A Rigorous Assessment and Optimization of the Linker Amplification Method. Environ. Microbiol. 2012, 14, 2526-2537. [CrossRef] [PubMed]

116. Karlsson, O.E.; Belák, S.; Granberg, F. The Effect of Preprocessing by Sequence-Independent, Single-Primer Amplification (SISPA) on Metagenomic Detection of Viruses. Biosecur. Bioterror. Biodef. Strategy Pract. Sci. 2013, 11, S227-S234. [CrossRef]

117. Li, J.; Pan, Y.Q.; Xu, Z.; Wang, Q.; Hang, D.; Shen, N.; Liu, M.; Zhang, C.; Abliz, A.; Deng, Q.; et al. Improved Detection of Human Papillomavirus Harbored in Healthy Skin with FAP6085/64 Primers. J. Virol. Methods 2013, 193, 633-638. [CrossRef] [PubMed]

118. Akgül, B.; Cooke, J.C.; Storey, A. HPV-Associated Skin Disease. J. Pathol. 2006, 208, 165-175. [CrossRef] [PubMed]

119. Hošnjak, L.; Komloš, K.F.; Kocjan, B.J.; Seme, K.; Poljak, M. Development of a Novel Multiplex Type-Specific Quantitative Realtime PCR for Detection and Differentiation of Infections with Human Papillomavirus Types HPV2, HPV27, and HPV57. Acta Dermatovenerol. APA 2016, 25, 65-71. [CrossRef]

120. Yeni, F.; Alpas, H. Vulnerability of Global Food Production to Extreme Climatic Events. Food Res. Int. 2017, 96, 27-39. [CrossRef]

121. Berger, C.N.; Sodha, S.V.; Shaw, R.K.; Griffin, P.M.; Pink, D.; Hand, P.; Frankel, G. Fresh Fruit and Vegetables as Vehicles for the Transmission of Human Pathogens. Environ. Microbiol. 2010, 12, 2385-2397. [CrossRef]

122. Kokkinos, P.; Kozyra, I.; Lazic, S.; Söderberg, K.; Vasickova, P.; Bouwknegt, M.; Rutjes, S.; Willems, K.; Moloney, R.; de Roda Husman, A.M.; et al. Virological quality of irrigation water in leafy green vegetables and berry fruits production chains. Food Environ. Virol. 2017, 9, 72-78. [CrossRef] 